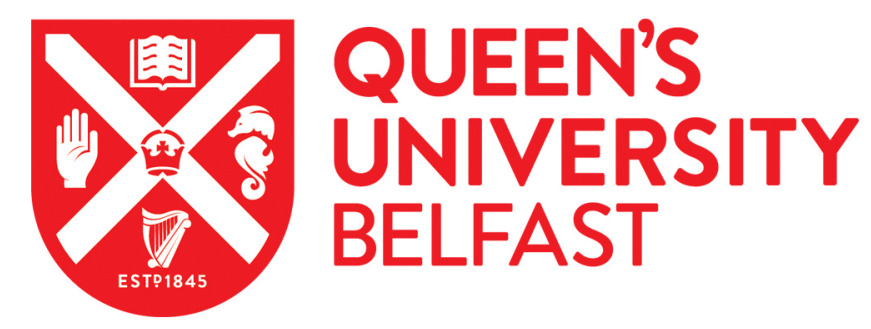

\title{
Investigating the pre-lethal cytotoxic effects of Bis(2,4-di-tert- butylphenyl)Phosphate on Chinese hamster ovary cells using high content analysis
}

Harper, E., Xie, Y., \& Connolly, L. (2021). Investigating the pre-lethal cytotoxic effects of Bis(2,4-di-tertbutylphenyl)Phosphate on Chinese hamster ovary cells using high content analysis. Journal of Biotechnology. https://doi.org/10.1016/j.jbiotec.2021.01.005

Published in:

Journal of Biotechnology

Document Version:

Peer reviewed version

Queen's University Belfast - Research Portal:

Link to publication record in Queen's University Belfast Research Portal

\author{
Publisher rights \\ Copyright 2021 Elsevier. \\ This manuscript is distributed under a Creative Commons Attribution-NonCommercial-NoDerivs License \\ (https://creativecommons.org/licenses/by-nc-nd/4.0/), which permits distribution and reproduction for non-commercial purposes, provided the \\ author and source are cited.
}

\section{General rights}

Copyright for the publications made accessible via the Queen's University Belfast Research Portal is retained by the author(s) and / or other copyright owners and it is a condition of accessing these publications that users recognise and abide by the legal requirements associated with these rights.

\section{Take down policy}

The Research Portal is Queen's institutional repository that provides access to Queen's research output. Every effort has been made to ensure that content in the Research Portal does not infringe any person's rights, or applicable UK laws. If you discover content in the Research Portal that you believe breaches copyright or violates any law, please contact openaccess@qub.ac.uk. 
$4 \quad$ Emma Harper ${ }^{1}$, Yuling Xie ${ }^{1}$, Lisa Connolly ${ }^{1}$.

$6{ }^{1}$ Institute for Global Food Security, School of Biological Sciences, 19 Chlorine Gardens, 7 BT9 5DL, Queen's University Belfast, Northern Ireland, UK.

$9 \quad$ Email: 1.connolly@qub.ac.uk

Abstract

Bis(2,4-di-tert-butylphenyl)Phosphate (bDtBPP) leaches out of polyethylene films used by the biopharmaceutical industry in single-use systems (SUS) for the culturing of drug producing cell lines. Previous studies found bDtBPP $(0.025-0.110 \mathrm{mg} / \mathrm{L})$ negatively affects Chinese hamster ovary $(\mathrm{CHO})$ cell growth and productivity. Less information is known about the potential early stages of subtle pre-lethal cytotoxic effects of bDtBPP. This study aimed to investigate the pre-lethal cytotoxic effects in CHO-K1 cells of bDtBPP $(0.005-0.25$ $\mu \mathrm{g} / \mathrm{ml}$ ) at process relevant concentrations following 2, 24 and $48 \mathrm{~h}$ exposure, using high content analysis to investigate multiple pre-lethal cytotoxicity markers.

After $48 \mathrm{~h}$ exposure, bDtBPP $(0.005-0.25 \mu \mathrm{g} / \mathrm{ml} ; P \leq 0.001)$ increased nuclear intensity. A dose- and time-dependent reduction in mitochondrial mass was seen after exposure to bDtBPP. Reactive oxygen species increased after $2 \mathrm{~h}$ exposure to $0.25 \mu \mathrm{g} / \mathrm{ml}$ bDtBPP, 24 and $48 \mathrm{~h}$ exposure to $0.05-0.25 \mu \mathrm{g} / \mathrm{ml}$ bDtBPP $(P \leq 0.01$ and $P \leq 0.001)$. BDtBPP induced subtle pre-lethal cytotoxic effects on CHO-K1 cellular health. 

switching to alternative SUS plastics which do not leach bDtBPP, which may enhance CHOK1 cell productivity.

Keywords: bDtBPP; Chinese hamster ovary cells; High content analysis; cellular health; pre-lethal cytotoxicity.

Abbreviations: bDtBPP, bis(2,4-di-tert-butylphenyl)Phosphate; CHO-K1, Chinese hamster ovary parental cells; $\mathrm{CN}$, cell number; NA, nuclear area; NI, nuclear intensity; MMP, mitochondrial membrane potential; MM, mitochondrial mass; ROS, reactive oxygen species, SUS, single-use systems. 


\section{Introduction}

The biopharmaceutical industry has implemented the investment of single-use systems (SUS) instead of traditional fixed stainless steel bioreactors throughout the manufacturing process. Flexible plastic polymeric bags utilized in SUS offer many advantages over stainless steel bioreactors such as eliminating energy and time consuming sterilization processes therefore reducing operational costs, allows more control over culture parameters such as $\mathrm{pH}$ and temperature and they have proved very efficient in the cultivation of cells (Butler and Meneses-Acosta, 2012; Kelly et al., 2016). However, SUS introduce possible concerns in relation to the suitability of the material and their potential to impact the bioprocess regarding performance, quality and patient safety (Liu et al., 2014).

The compound Bis(2,4-di-tert-butylphenyl)Phosphate (bDtBPP), a degradant of the antioxidant stabilizer Tris(2,4-di-tert-butylphenyl)phosphite (TBPP) commonly added to resin polymers and polyethylene-film used in single-use bioprocess bags. Single-use bioprocessing bag films containing bDtBPP are used in the biopharmaceutical production which involves using Chinese hamster Ovary $(\mathrm{CHO})$ cells that are genetically engineered to produce a therapeutic protein used for drug manufacturing (Hammond et al., 2013). BDtBPP has been reported to be a compound that leaches out of single-use bioprocess films into the cell culture media upon gamma-irradiation or sterilization by the process of autoclaving where TBPP becomes oxidised and breaks down forming the degradant bDtBPP (Liu et al., 2014). Numerous studies have investigated bDtBPP cytotoxic effects on CHO cell proliferation, sensitivity, growth and productivity (Hammond et al., 2013; Hammond et al., 2014; Kelly et al., 2016; Kelly et al., 2019). Hammond et al., (2014) found the disposable material bDtBPP to be cytotoxic to $\mathrm{CHO}$ cell lines and leaches out of certain film bags into cell culture media in concentrations (above $\approx 0.04$ to $0.05 \mathrm{mg} / \mathrm{L}$ ) that are deleterious to cell 
growth. In another study Kelly et al., (2016) demonstrated the leachate bDtBPP to reduce growth and productivity of $\mathrm{CHO}$ cell lines (parental nonproducing $\mathrm{CHO}-\mathrm{K} 1$ and $\mathrm{IgG}$ antibody producing $\mathrm{CHO}-\mathrm{DP} 12$ ) at concentrations as low as $0.035-0.1 \mathrm{mg} / \mathrm{L}$ with a reduction in cell viability at $0.25 \mathrm{mg} / \mathrm{L}$ after 4 days exposure using the Guava ViaCount assay. However, bDtBPP under normal incubation conditions was found to leach out of SUS bags and into cell culture media at $0.025-0.110 \mathrm{mg} / \mathrm{L}$ concentrations therefore, bDtBPP 0.25 $\mathrm{mg} / \mathrm{L}$ is higher than process relevant concentration levels (Hammond et al., 2014).

This study aims to investigate the potential of bDtBPP to induce pre-lethal cytotoxic effects on several cellular responses and metabolic activity using $\mathrm{CHO}-\mathrm{K} 1$ cells. In the current study, high content analysis (HCA) was used to study pre-lethal cytotoxic effects on cellular health in conjunction with the conventional gross metabolic cytotoxicity thiazolyl blue tetrazolium bromide (MTT) assay. The CHO-K1 cell line was used in this study due to its predominant choice in the pharmaceutical industry as a host for stable transfection and highly efficient production of recombinant therapeutic proteins for the last three decades (Butler and Meneses-Acosta, 2012). In the current study, bDtBPP concentrations tested $(0.005-0.25 \mu \mathrm{g} / \mathrm{ml})$ were based on previous studies which found bDtBPP to inhibit cell growth at concentrations ranging from $0.12-0.73 \mathrm{mg} / \mathrm{L}$ and exhibit sensitivity to bDtBPP exposure at concentrations $0.035-0.1 \mathrm{mg} / \mathrm{L}$ (Hammond et al., 2013; Kelly et al., 2016).

HCA is a highly sensitive, high-throughput and quantitative fluorescence technique that can examine chemical induced toxicity at sub-cellular microscopic resolution (Clarke et al., 2015; Wilson et al., 2016). It combines fluorescence microscopy with automated cell analysis software allowing the simultaneous assessment of multiple morphological and functional cell parameters (Abraham et al., 2004; Giuliano et al., 2004). HCA can be more beneficial than conventional cytotoxic assays such as the MTT assay due to its ability to identify subtle pre-lethal changes in cellular health and morphology at multiple endpoints 
providing substantially more information (Clarke et al., 2015; O’Brien and Haskins, 2007; Rinaldi et al., 2017). HCA measures very subtle effects on the health of cells including multiple pre-lethal and sub-cellular cytotoxicity parameters through the use of fluorescent chemical dyes. Hoechst 33342 dye can be used to measure nuclear parameters reflecting cellular health and nuclear morphology including cell number $(\mathrm{CN})$, nuclear area $(\mathrm{NA})$ and nuclear intensity (NI) (Wilson et al., 2016). Hoechst 33342 binds to and stains the adeninethymine-rich regions of the minor grove in DNA which renders it specific for nuclear chromatin in live cells. Its fluorescent intensity depends on the DNA content, chromatin structure and the position of the cell within the cell cycle, on binding to DNA, the fluorescence greatly increases. Hoechst 33342 can stain the condensed nuclei of apoptotic cells to allow the identification of chromatin condensation and fragmentation (Chazotte, 2011; Purschke et al., 2010).

MitoTracker Orange CMTMRos dye is positively charged and is rapidly taken up into the negatively charged mitochondria, suggesting that the uptake of the dye would be dependent on the mitochondrial membrane potential (MMP) and therefore can be used to measure mitochondrial function parameters such as MMP and mitochondrial mass (MM) (Buckman et al., 2001; Wilson et al., 2016). MitoTracker Orange CMTMRos dye accumulates in mitochondria allowing the MM to be measured whilst the MMP measures the intensity of the stained mitochondria (Cottet-Rousselle et al., 2011). Mitochondria are essential for cellular energy production, normal cellular function and dysfunction including calcium homeostasis, cell growth and differentiation, cell cycle control, apoptotic activation and cell death. Disruption in mitochondrial function can be related to cellular damage leading to endocrine related disease such as cancer and diabetes mellitus. Mitochondria morphology is important as it is associated with mitochondrial health and function (Kashatus, 2018). Mitochondrial morphology is determined by mitochondrial bioenergetics, a balance between 
the processes of fission and fusion, along with biogenesis and autophagy, ensuring an equilibrium state of organelle population (Duchen, 2000; Osellame et al., 2012; Silva et al., 2000; Susin et al., 1999). Changes in mitochondrial morphology are largely effected by disruption to fission and fusion homeostasis resulting in a heterogeneous population of organelles with non-uniform mitochondrial DNA (mtDNA) distribution, varied ability to produce adenosine triphosphate (ATP), and increased capacity to generate reactive oxygen species (ROS) and therefore increase the cells susceptibility to undergo apoptosis (Parone et al., 2008). Apoptosis is a form of programmed cell death which occurs through consequent morphological changes including cell shrinkage, plasma membrane blebbing, chromatin condensation, DNA fragmentation and formation of apoptotic bodies (Arends and Wyllie, 1991). Whereas, necrosis is a form of accidental cell death caused by a loss of membrane integrity, intracellular organelle swelling and ATP depletion leading to an increase in calcium levels (Camilleri-Broët et al., 1998; Li et al., 2018; Osellame et al., 2012).

CellROX Deep Red reagent is a fluorogenic probe designed to detect oxidative stress parameters measuring ROS intensity and ROS area. Upon oxidation, the CellROX Deep Red reagent exhibits a strong fluorogenic signal localised in the cytoplasm (Wilson et al., 2016). Excessive intracellular ROS can induce oxidative damage in cells and impair cellular functions (Harman, 1956).

In this study, a multi-parameter pre-lethal cytotoxicity analysis model for the CHOK1 cell line was optimised on the HCA platform, focusing on assay efficiency and sensitivity, optimal seeding density, fluorescent dye selection, cytotoxic control and concentration. Previous studies have found that the leachate bDtBPP leaches out of SUS bags at concentrations $(0.025-0.110 \mathrm{mg} / \mathrm{L})$ that affect $\mathrm{CHO}$ cell growth and productivity within biopharmaceutical production (Hammond et al., 2014). However, bDtBPP exposure can negatively affect cell growth and productivity at leaching concentrations before becoming 
cytotoxic and inducing cell death at concentrations above process relevant leaching concentrations $(0.25 \mathrm{mg} / \mathrm{L})$ (Kelly et al., 2016). Therefore, the overall aim of the study was to use the optimised model to assess early stage subtle pre-lethal cytotoxic effects in CHO-K1 cells following exposure to bDtBPP $(0.005-0.25 \mu \mathrm{g} / \mathrm{ml})$ at process relevant concentrations found to leach out of SUS bags into culture media. In addition, three exposure time-points were chosen to cover early cellular events/effects and the potential impact of bDtBPP on nuclear and mitochondrial health and morphology after 2, 24 and $48 \mathrm{~h}$ exposure.

\section{Methods}

\subsection{Chemicals and reagents}

Dimethyl sulfoxide (DMSO), menadione and thiazolyl blue tetrazolium bromide

(MTT) were obtained from Sigma-Aldrich (Poole, Dorset, UK). The cell culture reagents including phosphate-buffered saline (PBS), trypsin, F-12 Nutrient Mixture (Ham) media and general foetal bovine serum were supplied by Life Technologies (Paisley, UK). TrypLETM Express, trypan blue and CellROX Deep Red reagent was obtained from Life Technologies (Paisley, UK). Mitochondrial membrane potential dye (MMPD) MitoTracker Orange CMTMRos and Hoechst 33342 nuclear stain were purchased from ThermoFisher Scientific, UK. Triton ${ }^{\mathrm{TM}} \mathrm{X}-100$ solution was purchased from Analab, UK. Bis(2,4-di-tert-butylphenyl) Phosphate (bDtBPP) was supplied by Dublin City University (Dublin, Ireland).

\subsection{Cell Culture}

The Chinese Hamster Ovary parental (CHO-K1) cell line was obtained from SpectraGenetics, (USA) (ECACC catalogue number 85051005). The cell line was routinely grown in $75 \mathrm{~cm}^{2}$ tissue culture flasks (Nunc, Roskilde, Denmark) at $37^{\circ} \mathrm{C}$ with $5 \% \mathrm{CO}_{2}$ and 95\% humidity. The CHO-K1 cell line was routinely cultured in Ham's F-12 nutrient mixture and $1 \%$ penicillin-streptomycin. 
The Cellomics ${ }^{\circledR}$ High Content Screening reagent series multi-parameter cytotoxicity assay was performed according to the manufacturer's instructions. Multi-parameter cytotoxicity dyes, Hoechst 33342, MitoTracker Orange CMTMRos and CellROX Deep Red, were used following manufacturer's instructions. CHO-K1 cells were seeded at a density of 4 $\mathrm{x} 10^{4}$ cells $/ \mathrm{ml}$ in $96-$ well black plates with clear, flat bottoms. The cells were allowed to attach for 24 hours before being exposed to $100 \mu$ of bDtBPP $(0.005-0.25 \mu \mathrm{g} / \mathrm{ml})$ along with a cytotoxic control (menadione $50 \mu \mathrm{M}$ for 2 hour exposure and $10 \mu \mathrm{M}$ for 2,24 and 48 hour exposures) at a final DMSO concentration of $0.2 \%$. A solvent control of $0.2 \%(\mathrm{v}: \mathrm{v})$ DMSO in media was also included. The treated plates were incubated for periods of 2, 24 and 48 hours. The incubation periods were chosen to cover early cellular events/effects and the potential consequences after 2, 24 and 48 hour exposures. The MMPD MitoTracker Orange CMTMRos was prepared by adding $117 \mu \mathrm{l}$ of DMSO to $50 \mu \mathrm{g}$ of dye to make $1 \mathrm{mM}$ stock solution. The live cell staining solution was prepared by adding $5 \mu$ of the MMPD MitoTracker Orange CMTMRos in $5 \mathrm{ml}$ of F-12 Nutrient Mixture (Ham) media and $20 \mu \mathrm{l}$ of CellROX Deep Red reagent in $5 \mathrm{ml}$ of F-12 Nutrient Mixture (Ham) media for each assay plate. Following incubation, the plate was protected from light and $50 \mu 1$ of live cell stain added to each well for 30 mins at $37^{\circ} \mathrm{C}$. Cells were fixed with $10 \%$ formalin solution for 20 minutes at room temperature and washed with $200 \mu$ PBS twice. Hoechst 33342 nuclear stain was prepared by adding $1 \mu \mathrm{l}$ of Hoechst 33342 dye stock solution $(20 \mathrm{mM})$ to $10 \mathrm{ml}$ PBS and $0.5 \mathrm{ml}$ Triton ${ }^{\mathrm{TM}} \mathrm{X}-100$ solution. $100 \mu \mathrm{l}$ of Hoechst 33342 nuclear stain at a final concentration of $1.9 \mu \mathrm{M}$ was added to each well and incubated for 15 mins at room temperature. Following incubation the wells were washed with $200 \mu 1 \mathrm{PBS}$, then filled with $100 \mu \mathrm{l}$ PBS and sealed with a black plate sealer. 
(ThermoFisher Scientific, UK). Hoechst 33342 stained nuclei were read as primary targets in

the first channel (Ex/Em 350/461 nm). Fluorescent nuclei were segmented from neighbouring nuclei and evaluated based on nuclear morphology. Hoechst 33342 stain was used to measure nuclear parameters including cell number $(\mathrm{CN})$, nuclear area (NA), and nuclear intensity $(\mathrm{NI})$ for each well. MitoTracker Orange CMTMRos stained mitochondria as target in the second channel (Ex/Em 554/576 nm). MitoTracker Orange CMTMRos dye was used to measure mitochondrial function parameters such as mitochondrial membrane potential (MMP) and mitochondrial mass (MM). CellROX Deep Red reagent is a fluorogenic probe designed to measure reactive oxygen species (ROS) in live cells in the third channel (Ex/Em 640-665 nm). Signals from CellROX Deep Red reagent are localised in the cytoplasm and are used to detect oxidative stress parameters such as ROS intensity and ROS Area. Data was captured for each plate at $\mathrm{x} 20$ objective magnification. For each well, sixteen field view images were obtained to examine each parameter.

\subsection{Thiazolyl blue tetrazolium bromide (MTT) assay}

The Thiazolyl blue tetrazolium bromide (MTT) assay was used in parallel to HCA to measure cellular metabolic activity in CHO-K1 cells. CHO-K1 cells were seeded at $4 \times 10^{4}$ cells $/ \mathrm{ml}$ in clear, flat-bottomed $96-$ well plates and incubated for 24 hours. The test compound bDtBPP $(0.005-0.25 \mu \mathrm{g} / \mathrm{ml})$ at a final DMSO concentration of $0.2 \%$ and solvent control $(0.2 \%$ v:v DMSO in media) were added to the cells and incubated for 48 hours. The supernatant was discarded and cells washed once with $200 \mu \mathrm{l}$ PBS. Then, $50 \mu$ of thiazolyl blue tetrazolium bromide (MTT) solution $(2 \mathrm{mg} / \mathrm{ml}$ stock in PBS, diluted 1:6 in media) was added to each well and incubated for 3 hours at $37{ }^{\circ} \mathrm{C}$. In this assay, viable cells convert the soluble yellow MTT into insoluble purple formazan by the action of mitochondrial succinate dehydrogenase. The supernatant was removed and $200 \mu \mathrm{l}$ of dimethyl sulfoxide (DMSO) was 
added to each well to dissolve the formazan crystals. The plate was incubated at $37{ }^{\circ} \mathrm{C}$ for 10

211 minutes with agitation. Optical density (OD) was measured using a Sunrise

212 spectrophotometer (TECAN, Switzerland) at $570 \mathrm{~nm}$ with a reference filter at $630 \mathrm{~nm}$. All

213 samples were assessed in triplicate wells and in three independent exposures. Viability was

214 calculated as the percentage absorbance of the sample when compared with the absorbance of 215 the solvent control.

\subsection{Statistical Analysis}

HCA pre-lethal cytotoxicity and MTT assays were carried out in triplicate and in three independent exposures $(n=3)$. The coefficient of variation $(\mathrm{CV})$ was calculated for the three exposures; all parameters were below 15\% except for the ROS intensity which was below 25\%. Data collected from the HCA platform was processed with Excel and Graphpad PRISM software version 6.0 (San Diego, CA). All values shown are expressed as mean \pm standard error of the mean (SEM) of three independent exposures for the compound tested. Data is expressed as a percentage of the relevant solvent control for each parameter and analysed by one-way ANOVA followed by Dunnett's procedure for multiple comparisons; the mean concentrations were tested for significant difference at the $95 \%$ confidence level.

226 Significant effects are represented by $P \leq 0.05\left(^{*}\right), P \leq 0.01(* *)$ and $P \leq 0.001\left(^{* * *}\right)$. 


\section{Results}

Multiple nuclear and mitochondrial pre-lethal cytotoxicity markers were assessed in this study in CHO-K1 cells following 2, 24 and $48 \mathrm{~h}$ exposure to bDtBPP $(0.005-0.25$ $\mu \mathrm{g} / \mathrm{ml})$. Hoechst 33342 nuclear stain was used to obtain information on cellular health; measuring cell number $(\mathrm{CN})$, nuclear area (NA) and nuclear intensity (NI). MitoTracker Orange CMTMRos was used to provide information on mitochondrial health; measuring mitochondrial membrane potential (MMP) and mitochondrial mass (MM). CellROX Deep Red reagent was used to detect oxidative stress parameters such as reactive oxygen species (ROS) intensity and ROS area. Parallel to the HCA, cytotoxicity and metabolic activity were also measured using the MTT assay.

\subsection{Optimisation of the pre-lethal cytotoxicity assay and HCA reading}

Valinomycin was initially used as a cytotoxic control as it was previously identified to cause cell death by inducing apoptosis in $\mathrm{CHO}$ cells via several apoptotic events (Abdalah et al., 2006). However, after the first assay run, the method was optimized; the cytotoxic control, valinomycin $(2 \mu \mathrm{M})$, should have increased the formation of ROS and oxidative stress when compared to the solvent control (DMSO 0.2\%) however, in this study a reduction in ROS was observed when compared to the solvent control (Fig 1a, b and e). In the presence of valinomycin, a reduction in the formation of ROS may be due to the depolarizing effect of voltage-dependent potassium influx (Akopova et al., 2013). The cytotoxic control was changed from valinomycin to menadione $50 \mu \mathrm{M}$, as menadione had previously been found to induce ROS production when compared to the solvent control (Wilson et al., 2016). After 24 h exposure to $50 \mu \mathrm{M}$ menadione, no cells were observed, likely due to cytotoxicity at this concentration over $24 \mathrm{~h}$. The cytotoxic control for 24 and $48 \mathrm{~h}$ was altered to $10 \mu \mathrm{M}$ menadione; whilst the $2 \mathrm{~h}$ exposure contained both 10 and $50 \mu \mathrm{M}$ menadione (Fig $1 \mathrm{a}, \mathrm{b}$ and 
c). The cell seeding density was reduced from $6 \times 10^{4}$ cells $/ \mathrm{ml}$ to $4 \times 10^{4}$ cells $/ \mathrm{ml}$ to reduce 253 cell confluency in the wells. The CHO-K1 cell population after 2, 24 and $48 \mathrm{~h}$ exposure to the 254 solvent control is presented in Fig. 2 a, b and c. 

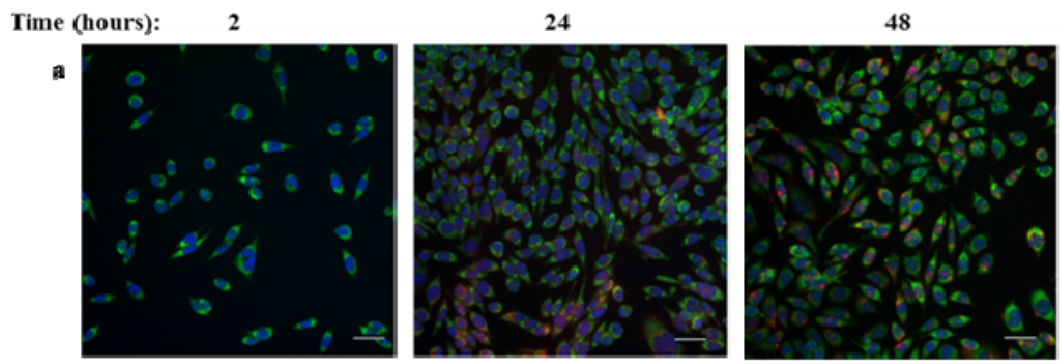

b
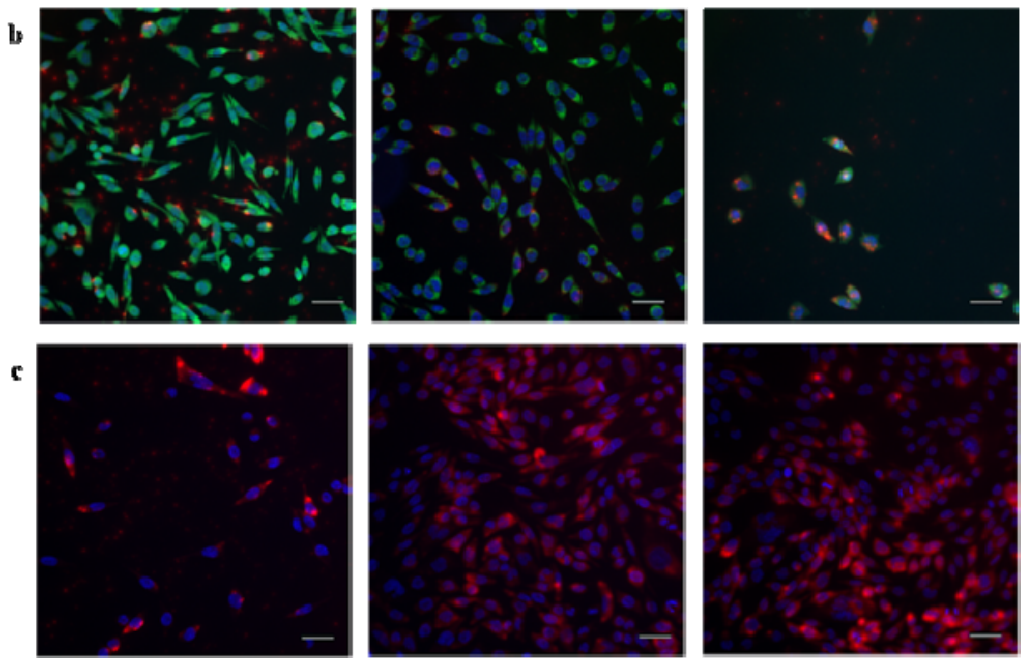

d
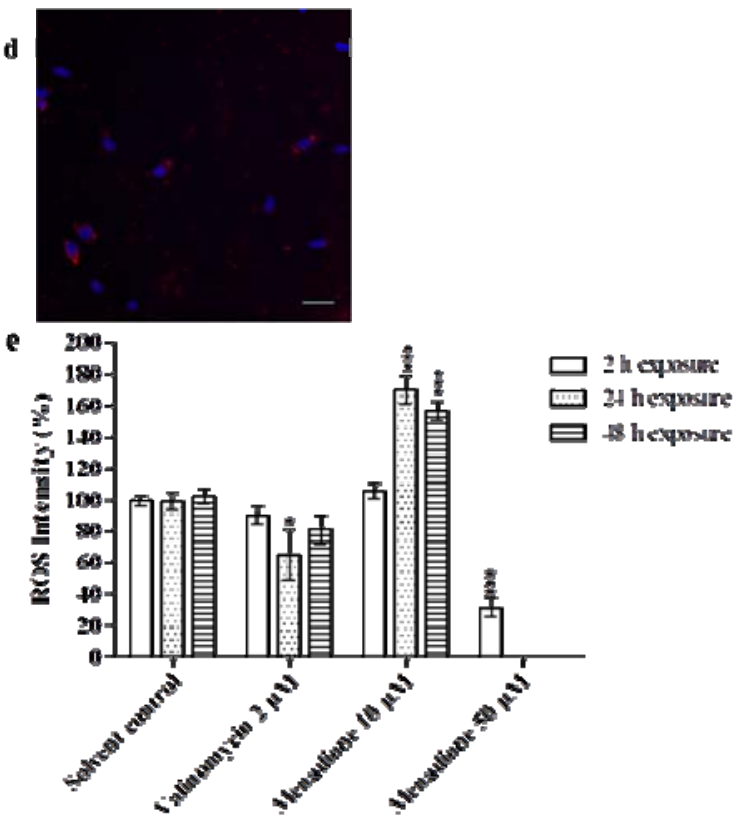

bDtBPP( $\mu \mathrm{g} / \mathrm{mL})$

Fig. 1. High content analysis composite channel images of CHO-K1 cells after exposure to the (a) solvent control (DMSO 0.2\%), cytotoxic controls (b) valinomycin $2 \mu \mathrm{M}$ and (c) menadione $10 \mu \mathrm{M}$ after 2, 24 and $48 \mathrm{~h}$ and (d) menadione $50 \mu \mathrm{M}$ after $2 \mathrm{~h}$ exposures. Typical HCA micrographs are shown with nuclei (stained by Hoechst 33342, shown in blue), mitochondrial structure (stained by MitoTracker Orange CMTMRos, shown in green) and ROS (stained by CellROX Deep Red, shown in red) $\mathrm{x} 20$ objective magnification, scale bars $=200 \mu \mathrm{m}$. (e) Changes in ROS intensity in CHO-K1 cells following exposure to solvent control (DMSO 0.2\%) and cytotoxic controls (valinomycin $2 \mu \mathrm{M}$, 
265 menadione 10 and $50 \mu \mathrm{M}$ ) after 2, 24 and 48 hours measured by HCA. Data is expressed as a 266 percentage of solvent control; mean \pm standard error of the mean (SEM), $n=3 . P \leq 0.05(*) \mathrm{P} \leq 0.001$ $267(* * *)$. 


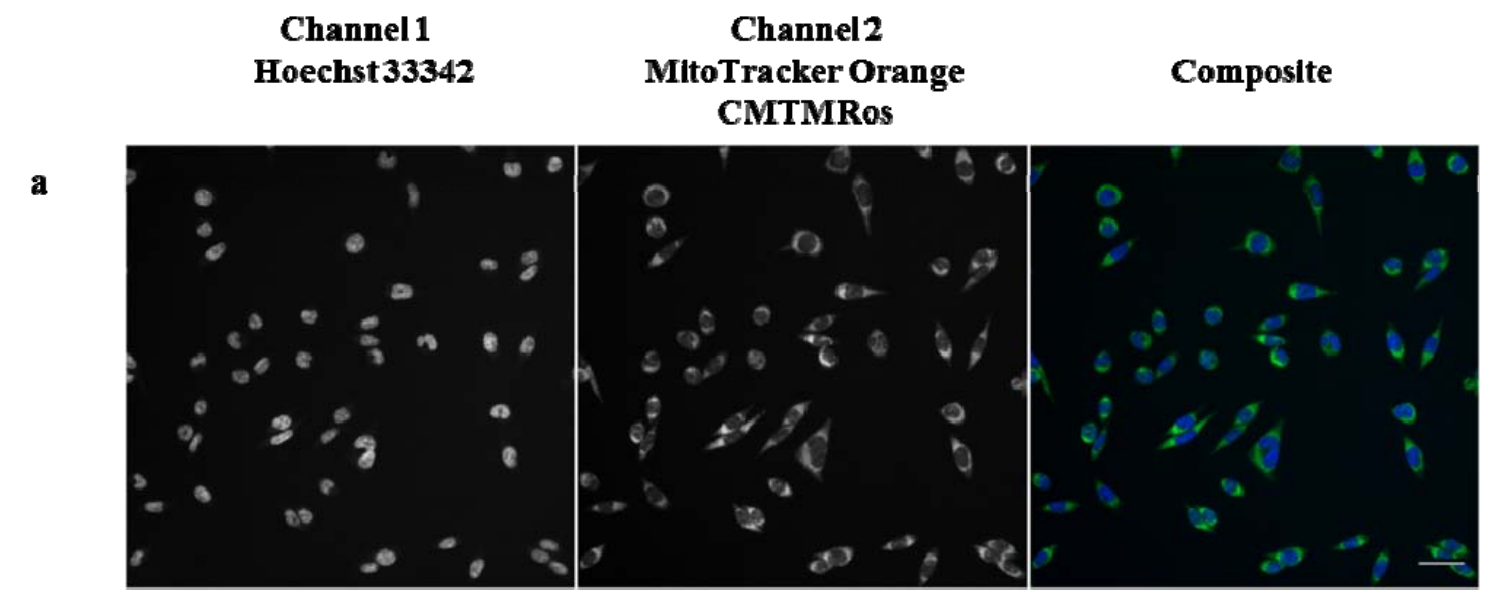

b

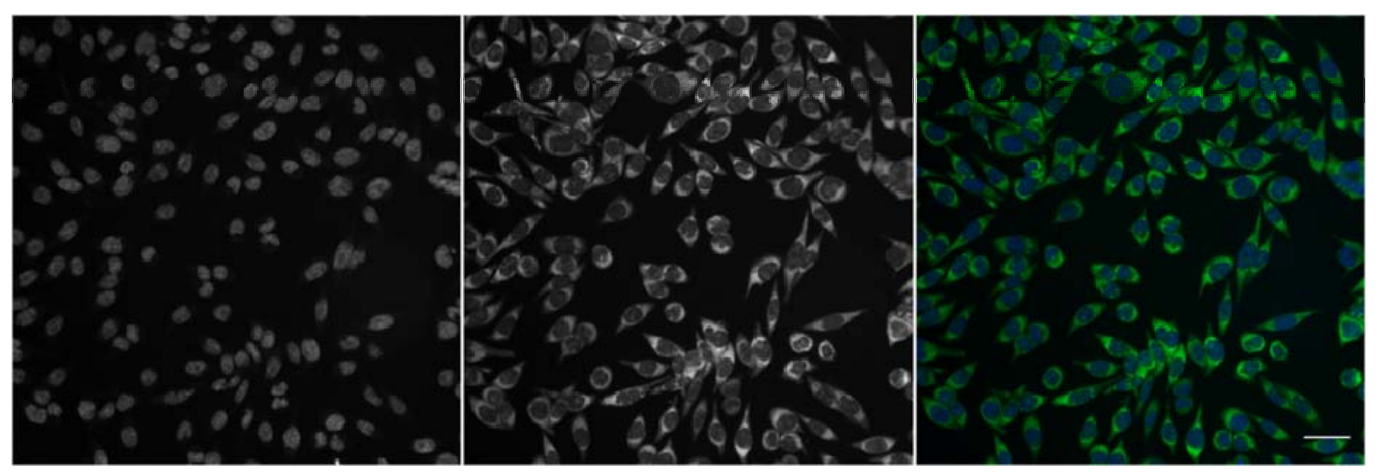

\section{c}

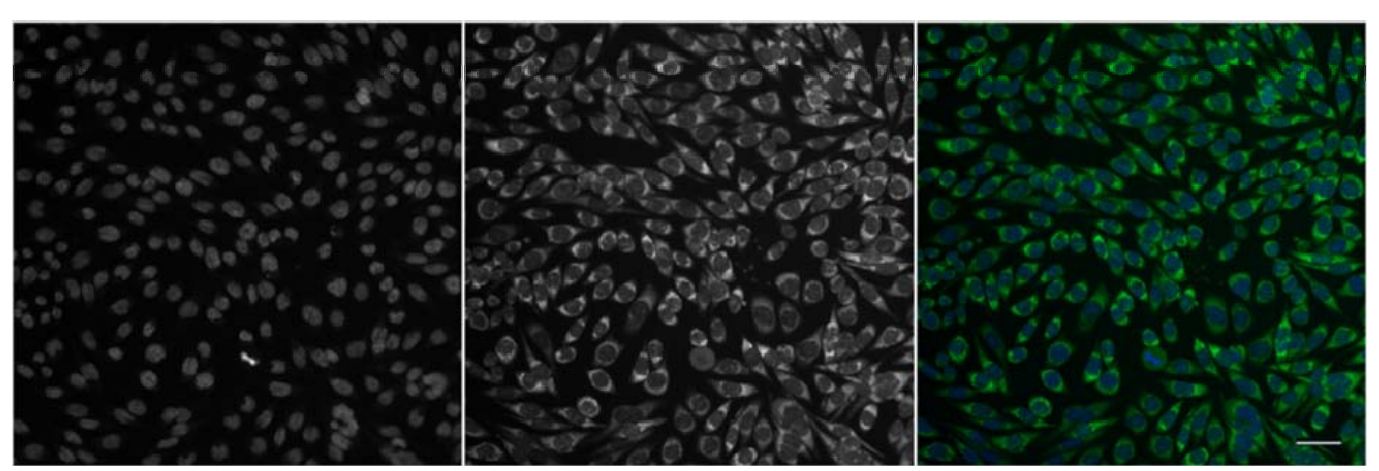

270 Fig. 2. High content analysis images of CHO-K1 cells after exposure to the solvent control (DMSO $2710.2 \%$ ) after (a) 2, (b) 24 and (c) $48 \mathrm{~h}$ exposures showing the CHO-K1 cell population over time. 272 Typical HCA micrographs are shown with nuclei (stained by Hoechst 33342, shown in blue) and 273 mitochondrial structure (stained by MitoTracker Orange CMTMRos, shown in green) x 20 objective 274 magnification, scale bars $=200 \mu \mathrm{m}$. Dyes are stated in the image, with composite images containing 275 channels 1 and 2. 
In the first assay run, the CHO-K1 cells were stained with all three dyes, Hoechst

33342, MitoTracker Orange CMTMRos and CellROX Deep Red and run together on the

280

HCA (Fig. 3a). However, running the three dyes together induced high variations in ROS.

281

Consequently, the dyes were applied using two separate plates in further runs, where in one

282 plate the CHO-K1 cells were stained with Hoechst 33342 and MitoTracker Orange

CMTMRos and the second plate the CHO-K1 cells were stained with Hoechst 33342 and

CellROX Deep Red as shown in table 1. CellROX Deep Red uptake was improved as presented in Fig. $3 \mathrm{~b}$ and ROS variations were reduced. The paper Wilson et al, (2016) also found high variations in ROS production using MitoTracker Orange CMTMRos and

CellROX Deep Red as the CV (\%) calculated for three exposures was above the ideal target (15\%) but below 25\%. Fig. 3 shows HCA images of CHO-K1 cells after $2 \mathrm{~h}$ exposure to bDtBPP $(0.25 \mu \mathrm{g} / \mathrm{ml})$ showing differences in fluorescent signal upon oxidation (ROS production) stained with (a) Hoechst 33342, MitoTracker Orange CMTMRos and CellROX

Deep Red dyes and (b) Hoechst 33342 and CellROX Deep Red dyes.

Table 1 Optimization of the fluorescent chemical dyes used in the HCA assay runs. $\checkmark$ shows the use of the dye while $x$ shows omitting the dye from the run.

\begin{tabular}{cccc}
\hline & $\begin{array}{c}\text { Hoechst 33342 } \\
\text { nuclear stain }\end{array}$ & $\begin{array}{c}\text { MitoTracker } \\
\text { Orange } \\
\text { CMTMRos dye }\end{array}$ & $\begin{array}{c}\text { CellROX Deep } \\
\text { Red reagent }\end{array}$ \\
\hline First assay run & $\checkmark$ & $\checkmark$ & $\checkmark$ \\
\hline Second assay run plate 1 & $\checkmark$ & $\checkmark$ & $\checkmark$ \\
\hline Second assay run plate 2 & $\checkmark$ & $x$ & \\
\hline
\end{tabular}


Channel 1

Hoechst 33342
Channel 2 MitoTracker Orange CMTMRos

a

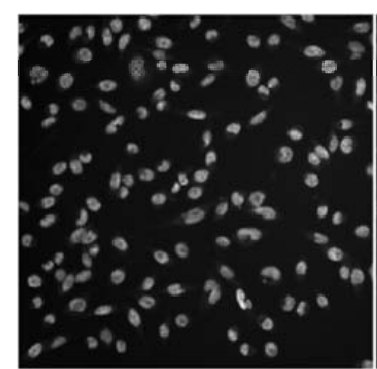

Channel 1 Hoechst 33342

Channel 2 CellROX Deep Red
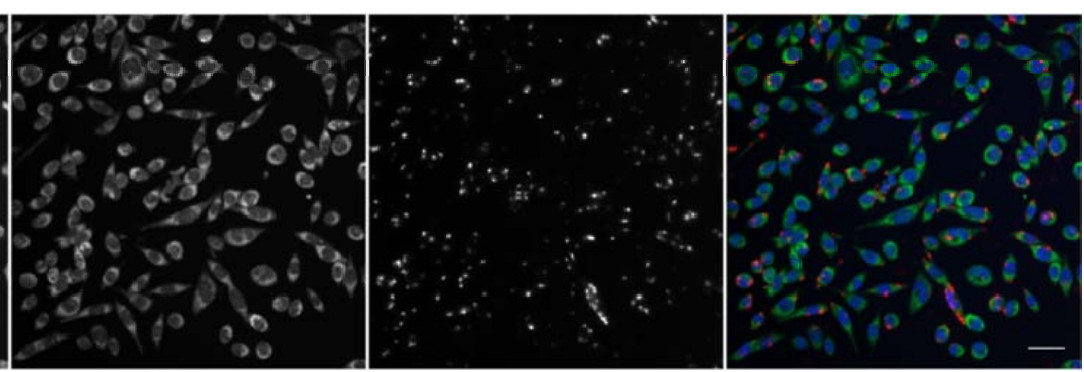
Composite

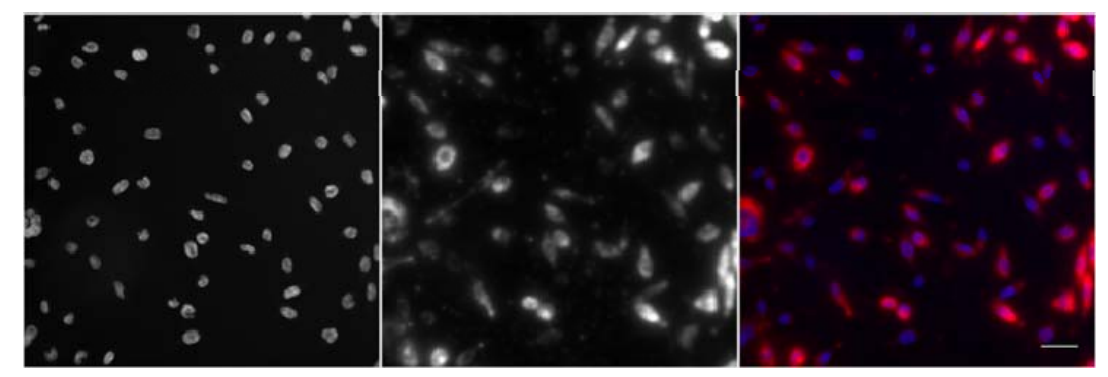

298 Fig. 3. High content analysis images of CHO-K1 cells after $2 \mathrm{~h}$ exposure to bDtBPP $(0.25 \mu \mathrm{g} / \mathrm{ml})$ 299 showing differences in fluorescent signal upon oxidation (ROS production) stained with (a) Hoechst 300 33342, MitoTracker Orange CMTMRos and CellROX Deep Red dyes and (b) Hoechst 33342 and 301 CellROX Deep Red dyes. Dyes are stated in the image, with composite images containing channels 302 (a) 1,2 and 3 and (b) 1 and 2. Typical HCA micrographs are shown with nuclei (stained by Hoechst 303 33342, shown in blue), mitochondrial structure (stained by MitoTracker Orange CMTMRos, shown in 304 green) and ROS (stained by CellROX Deep Red, shown in red) x 20 objective magnification, scale 305 bars $=200 \mu \mathrm{m}$. 
3.2. Metabolic activity as measured by MTT assay

Gross cellular cytotoxicity was investigated in the CHO-K1 cells by quantifying metabolic activity using MTT conversion. No significant effects on metabolic activity of

311 CHO-K1 cells were induced by bDtBPP $(0.005-0.25 \mu \mathrm{g} / \mathrm{ml})$ compared to the solvent control

313 significantly, there was a 5.1\% reduction in metabolic activity at the highest concentration of

314 bDtBPP $(0.25 \mu \mathrm{g} / \mathrm{ml})$ after $48 \mathrm{~h}$. The results suggest that there may be cytotoxic effects starting to occur therefore HCA was employed to detect subtle pre-lethal health markers of the exposed cells.

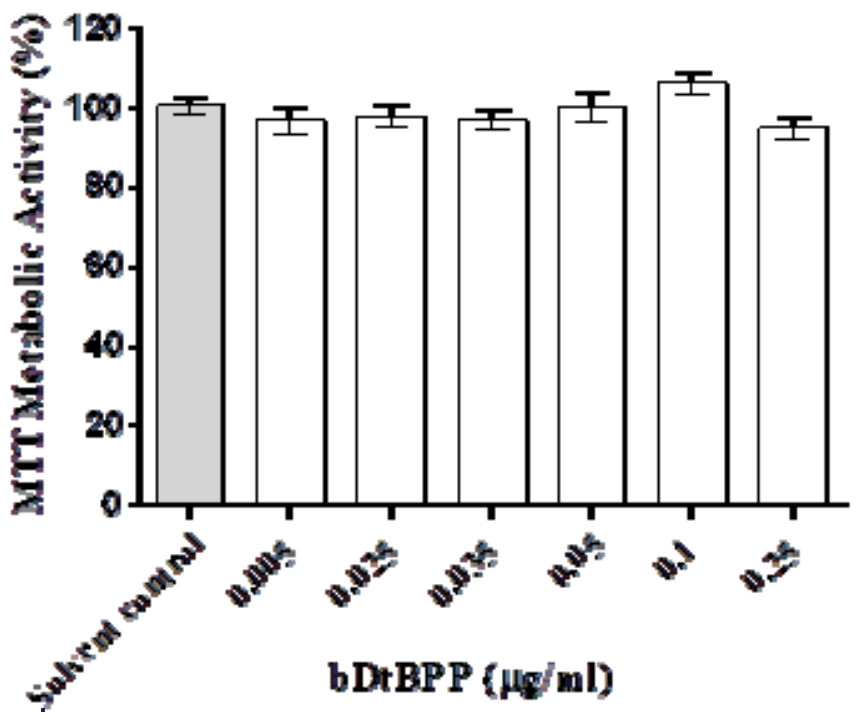

Fig. 4. MTT metabolic activity of CHO-K1 cells after exposure to bDtBPP $(0.005-0.25 \mu \mathrm{g} / \mathrm{ml})$ and solvent control (DMSO 0.2\%). Data is expressed as percentage of solvent control (DMSO 0.2\% $\mathrm{v}: \mathrm{v})$; mean \pm standard error of the mean (SEM), $\mathrm{n}=3$. 
323 3.3. Pre-lethal cytotoxicity as measured by cell number (CN), nuclear area (NA), and nuclear 324 intensity (NI)

325 In agreement with the MTT cell viability results, CN did not significantly reduce. 326 However, not significantly, there was a $7.6 \%$ reduction in cell number at the highest 327 concentration of bDtBPP after $48 \mathrm{~h}$ (data not shown). After 24 and $48 \mathrm{~h}$ the cytotoxic control 328 menadione $50 \mu \mathrm{M}$ was cytotoxic to the CHO-K1 cells and reduced the cell number to 0 . No 329 significant decrease in NA was observed following 2, 24 or $48 \mathrm{~h}$ at all tested concentrations 330 (data not shown). However, not significantly, there was a $4.43 \%$ and $6.18 \%$ reduction in NA 331 after exposure to the highest concentration of bDtBPP after 24 and $48 \mathrm{~h}$, respectively (data 332 not shown).

NI significantly increased after $48 \mathrm{~h}$ exposure at all tested concentrations of bDtBPP $(0.005-0.25 \mu \mathrm{g} / \mathrm{ml}), 122.20 \%, 119.54 \%, 123.06 \%, 125.78 \%, 126.32 \%$ and $127.15 \%$ respectively $(P \leq 0.001)$ when compared to the solvent control, Fig. 5 . No significant increase in NI was observed following 2 or 24 h exposure. It can be observed in Fig. 6 an increase in brightness and blue intensity of the nuclei after $48 \mathrm{~h}$ exposure to bDtBPP $0.25 \mu \mathrm{g} / \mathrm{ml}$ compared to $2 \mathrm{~h}$. 


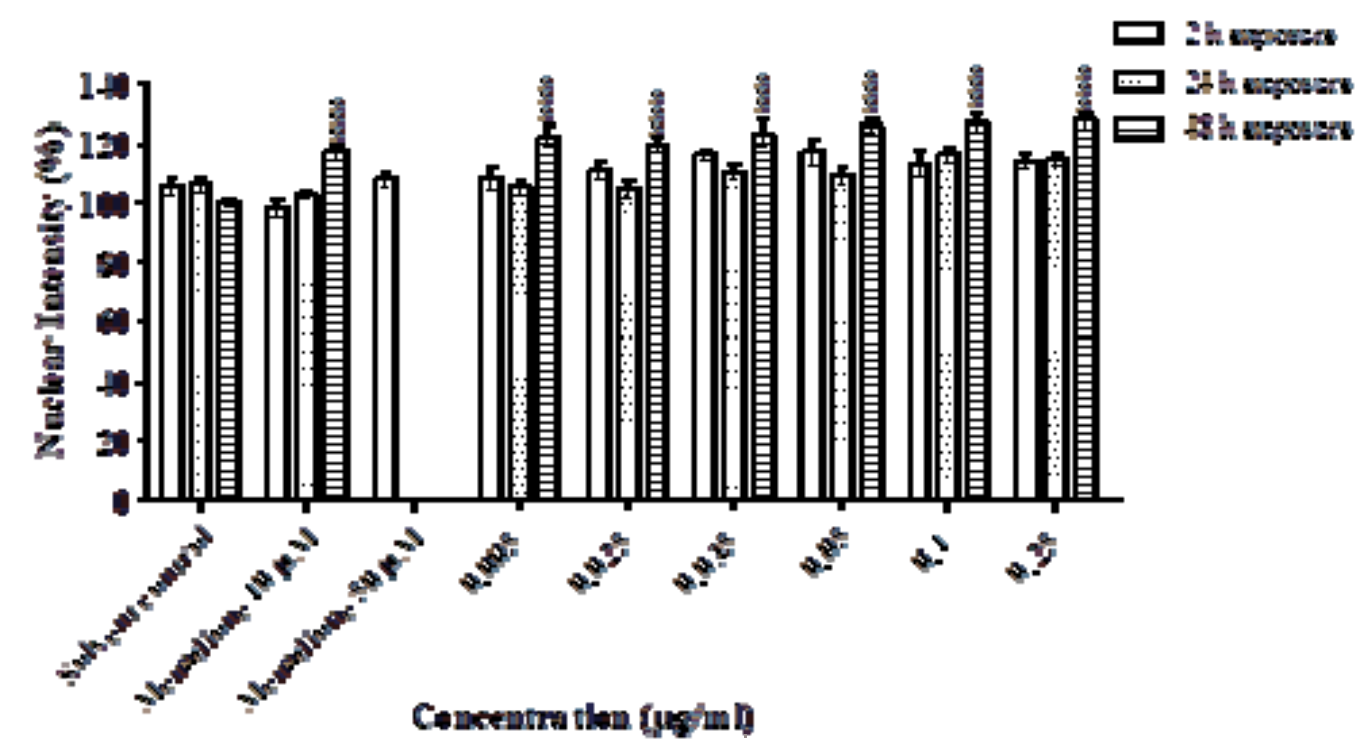

Fig. 5. Nuclear intensity changes in CHO-K1 cells following exposure to bDtBPP $(0.005-0.25$ $\mu \mathrm{g} / \mathrm{ml}$ ), solvent control (DMSO 0.2\%) and cytotoxic controls (menadione 10 and $50 \mu \mathrm{M}$ ) after 2, 24 and 48 hours measured by HCA. Data is expressed as a percentage of solvent control (DMSO $0.2 \%$ $\mathrm{v}: \mathrm{v})$; mean \pm standard error of the mean (SEM), $\mathrm{n}=3$. $\mathrm{P} \leq 0.001(* * *)$ represent significant pre-lethal cytotoxic effects.

Channel 1

Hoechst 33342
Channel 2

MitoTracker Orange CMTMRos

a

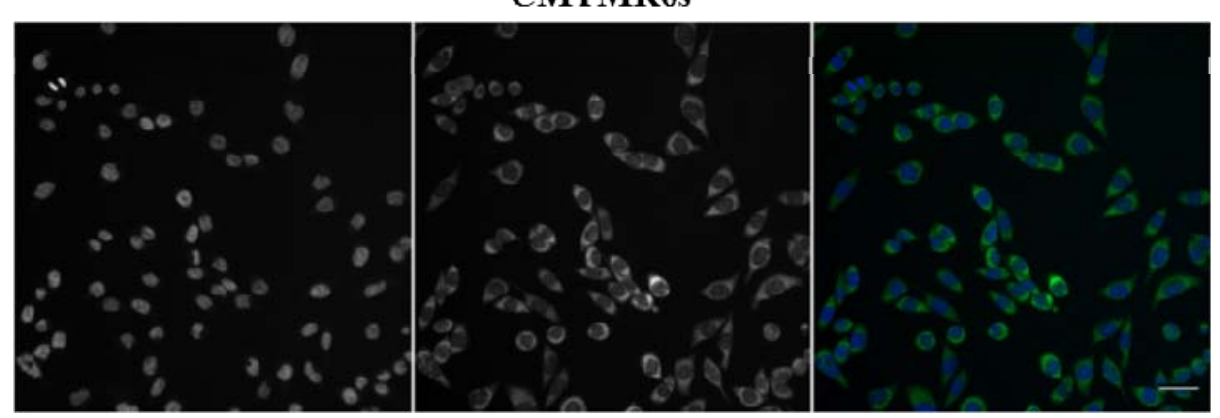

b

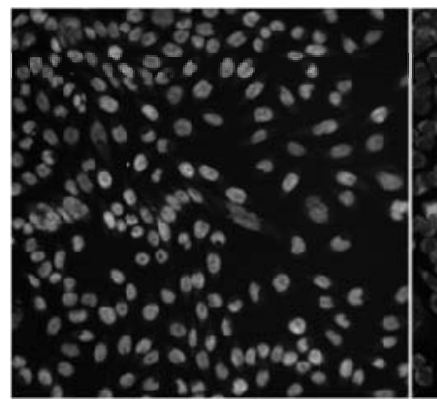

Composite

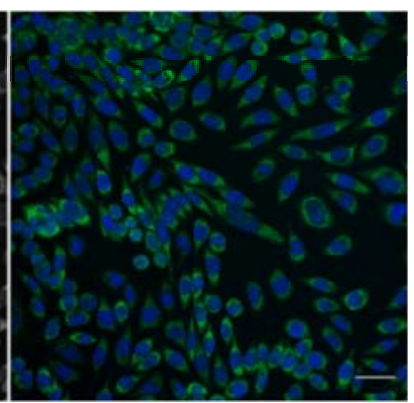

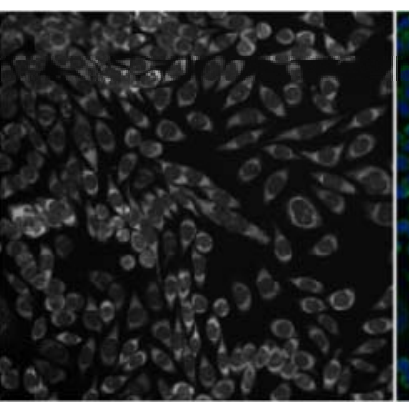

Fig. 6. High content analysis images of nuclear intensity changes in CHO-K1 cells after (a) 2 and (b) $48 \mathrm{~h}$ exposure of bDtBPP $0.25 \mu \mathrm{g} / \mathrm{ml}$. Typical HCA micrographs are shown with nuclei (stained by Hoechst 33342, shown in blue) and mitochondrial structure (stained by MitoTracker Orange CMTMRos, shown in green) $\times 20$ objective magnification, scale bars $=200 \mu \mathrm{m}$. Dyes are stated in the image, with composite images containing channels 1 and 2. 
352 3.4. Pre-lethal cytotoxicity as measured by mitochondrial membrane potential (MMP) and

353

354

355

356

357

358

359

360

361

362

363

364

365 mitochondrial mass (MM)

No significant change in MMP was observed at any bDtBPP tested concentrations following exposure for 2, 24 and $48 \mathrm{~h}$ (data not shown). After $24 \mathrm{~h}$ exposure, a significant decrease in MM was observed for bDtBPP $0.035,0.05,0.1$ and $0.25 \mu \mathrm{g} / \mathrm{ml}$, to $90.56,89.38$, 88.47 and $87.27 \%$, respectively $(P \leq 0.05$ and $P \leq 0.01)$. After $48 \mathrm{~h}$, all concentrations of bDtBPP $(0.005-0.25 \mu \mathrm{g} / \mathrm{ml})$ were found to significantly decrease $\mathrm{MM}$, to $89.49,86.31$, 85.42, 81.67, 79.72 and 76.18\% $(P \leq 0.01$ and $P \leq 0.001)$ (Fig. 7). After 24 and $48 \mathrm{~h}$ the cytotoxic control menadione $50 \mu \mathrm{M}$ was cytotoxic to the $\mathrm{CHO}-\mathrm{K} 1$ cells, reducing the cell number to 0 therefore the MM result showed a decrease of $100 \%$ (Fig. 7). Changes in mitochondrial mass can be observed in the HCA images of CHO-K1 cells in Fig. 8, as a decrease in green staining of the mitochondria can be seen when comparing the solvent control (DMSO 0.2\%) image to $0.25 \mu \mathrm{g} / \mathrm{ml}$ bDtBPP. The changes in mitochondrial morphology provide information regarding the mitochondrial health of the cells. 


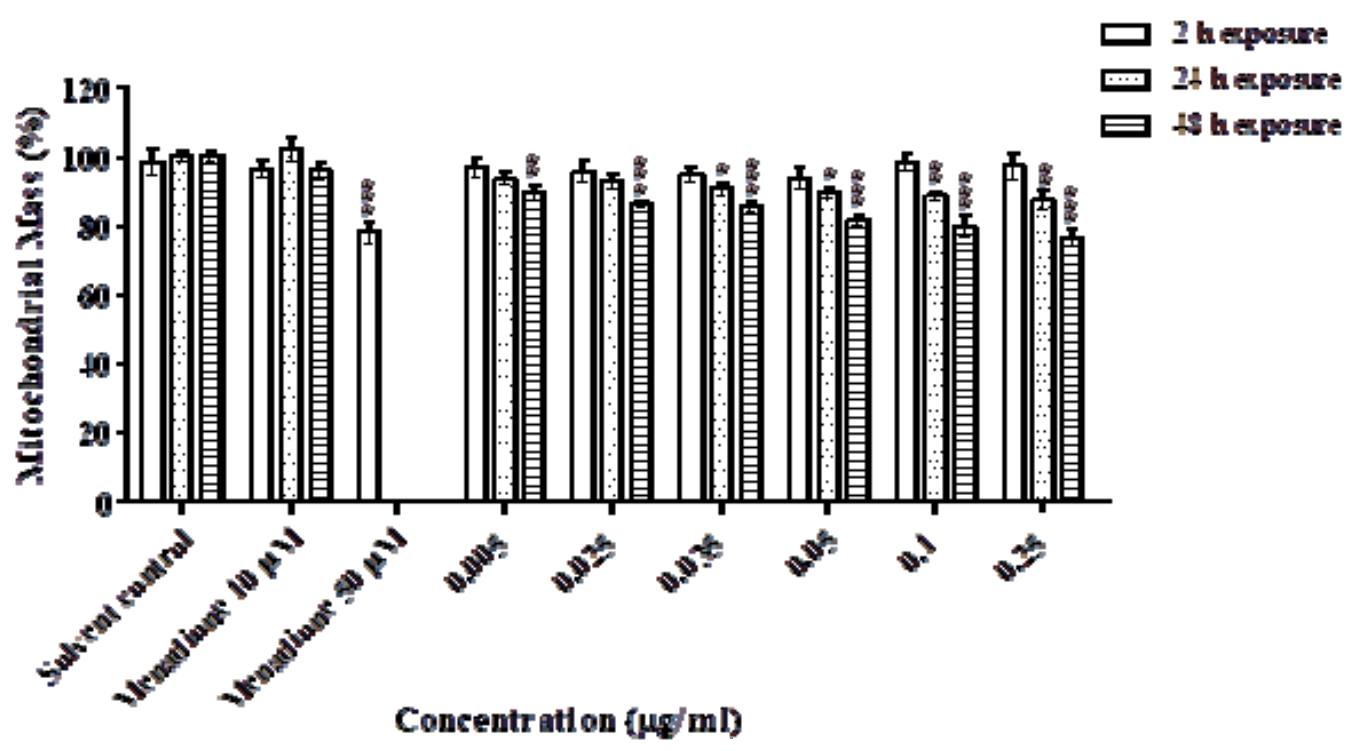

367

368 Fig. 7. Mitochondrial mass changes in CHO-K1 cells following exposure to bDtBPP $(0.005-0.25$ $369 \mu \mathrm{g} / \mathrm{ml}$ ) solvent control (DMSO 0.2\%) and cytotoxic controls (menadione 10 and $50 \mu \mathrm{M}$ ) after 2, 24 370 and 48 hours measured by HCA. Data is expressed as a percentage of untreated control; mean \pm 371 standard error of the mean (SEM), $\mathrm{n}=3 . \mathrm{P} \leq 0.05\left(^{*}\right), \mathrm{P} \leq 0.01(* *) \mathrm{P} \leq 0.001(* * *)$ represent 372 significant pre-lethal cytotoxic effects. 
Channel 1 Hoechst 33342
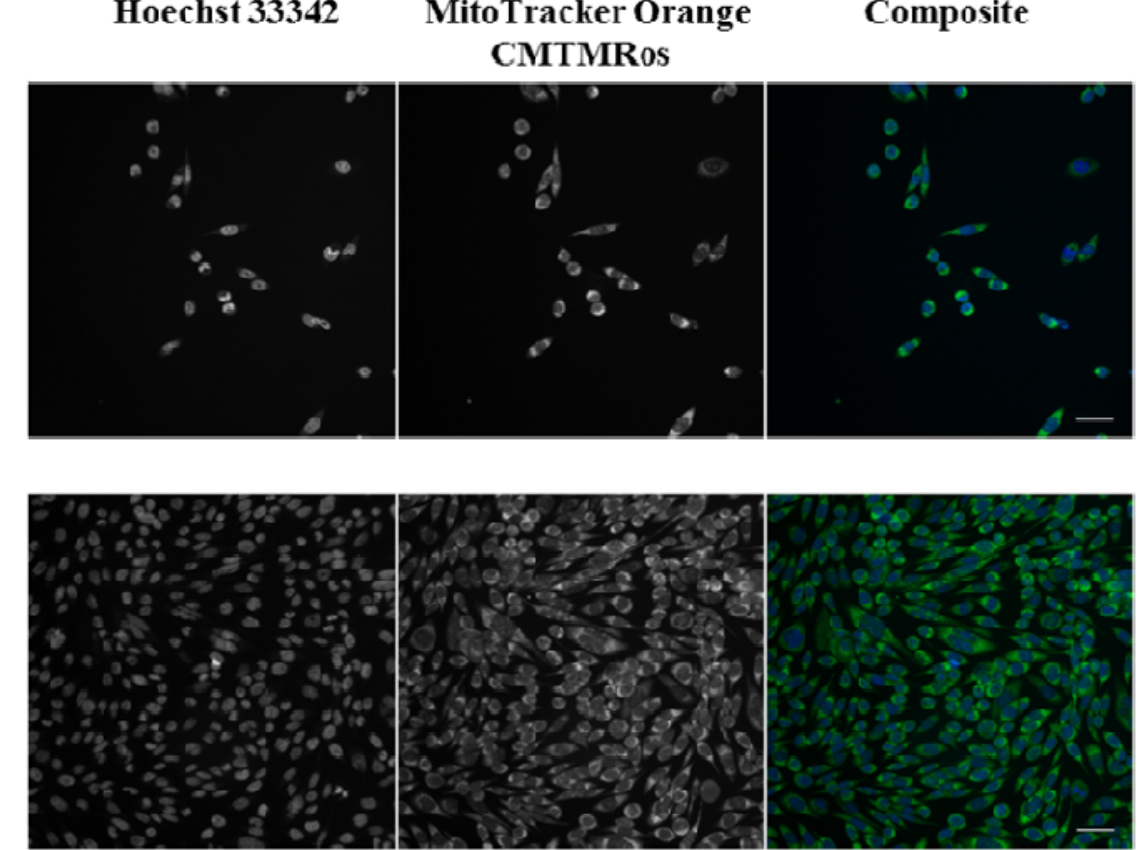

Channel 1 Hoechst 33342

Channel 2 MitoTracker Orange CMTMRos
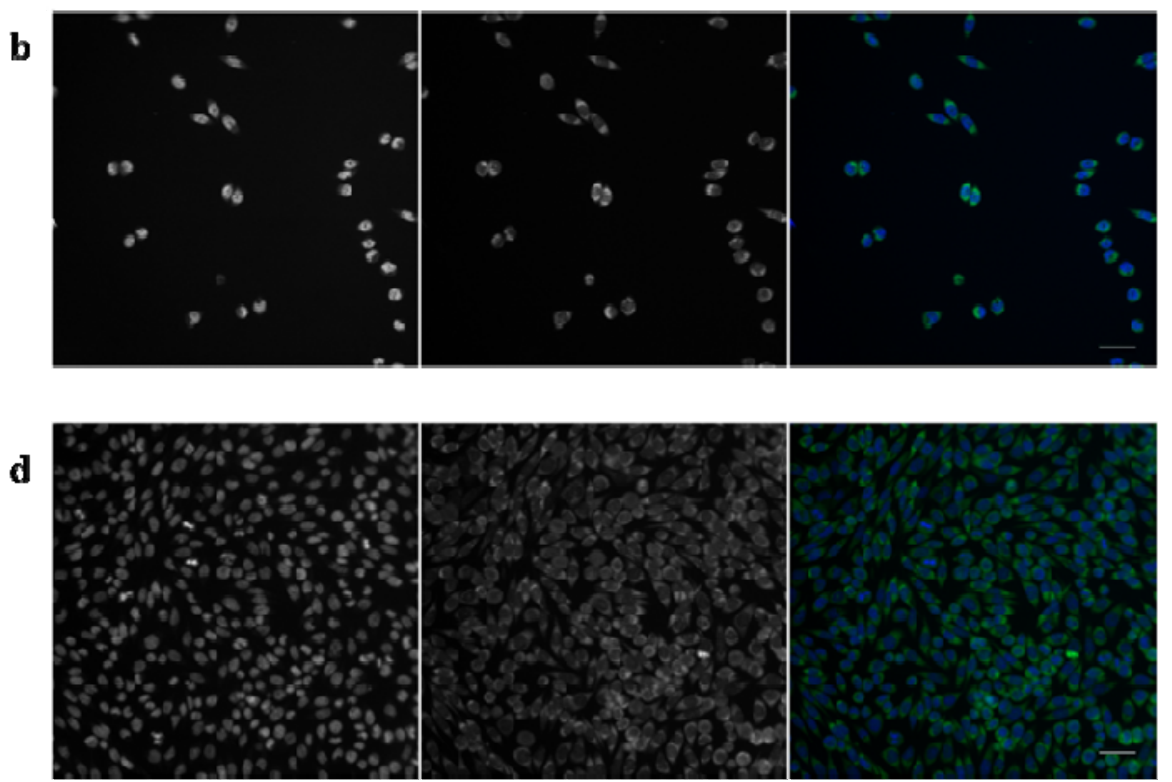

Fig. 8. High content analysis images of mitochondrial mass changes in CHO-K1 cells after $2 \mathrm{~h}$ exposure of (a) solvent control (DMSO 0.2\%), (b) bDtBPP $0.25 \mu \mathrm{g} / \mathrm{ml}$ and after $48 \mathrm{~h}$ exposure of (c) solvent control (DMSO 0.2\%) and (d) bDtBPP $0.25 \mu \mathrm{g} / \mathrm{ml}$. Typical HCA micrographs are shown with nuclei (stained by Hoechst 33342, shown in blue) and mitochondrial structure (stained by MitoTracker Orange CMTMRos, shown in green) x20 objective magnification, scale bars $=200 \mu \mathrm{m}$. Dyes are stated in the image, with composite images containing channels 1 and 2. 
4.3.5 Cellular health as measured by oxidative stress parameters ROS intensity and ROS

Area

When compared to the solvent control (DMSO 0.2\%) exposure, a significant increase in ROS intensity was observed after $2 \mathrm{~h}$ exposure to $0.25 \mu \mathrm{g} / \mathrm{ml} \mathrm{bDtBPP}, 24$ and $48 \mathrm{~h}$ exposure to $0.05,0.1$ and $0.25 \mu \mathrm{g} / \mathrm{ml}$ bDtBPP (Fig. 9). A significant dose and time-dependent increase in ROS intensity was observed after 24 and $48 \mathrm{~h}(P \leq 0.01$ and $P \leq 0.001)$ exposure to bDtBPP. The increase in red fluorescence after $48 \mathrm{~h}$ exposure of the cytotoxic control (menadione $10 \mu \mathrm{M})$ and the highest concentration of bDtBPP $(0.25 \mu \mathrm{g} / \mathrm{ml})$ compared to the solvent control can be seen in Fig. 10. However, no significant change in ROS area was observed at any bDtBPP tested concentrations following exposure for 2, 24 and $48 \mathrm{~h}$ (data not shown).

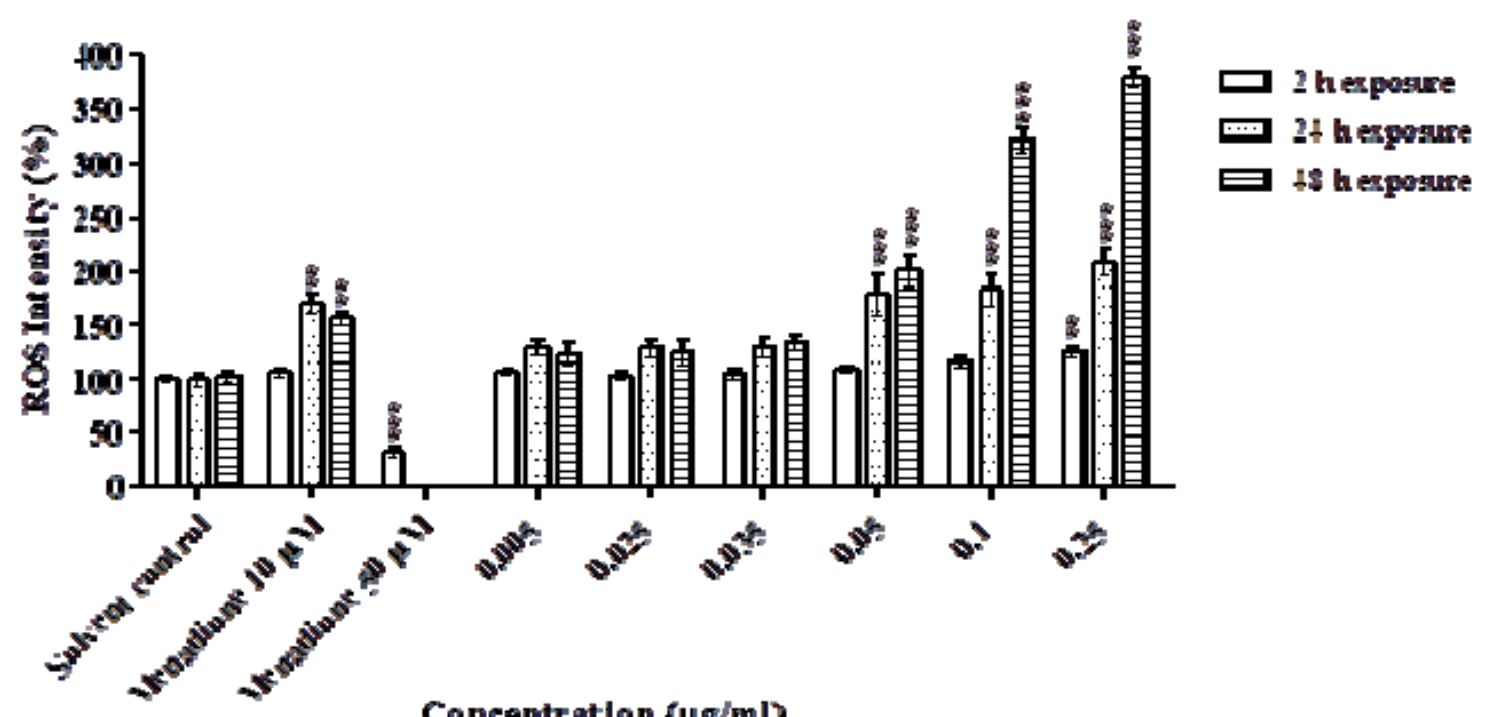

\section{Concentration $\{\mu \mathrm{g} / \mathrm{ml}\}$}

Fig. 9. Changes in ROS intensity in CHO-K1 cells following exposure to bDtBPP $(0.005-0.25$ $\mu \mathrm{g} / \mathrm{ml}$ ), solvent control (DMSO 0.2\%) and cytotoxic controls (menadione 10 and $50 \mu \mathrm{M}$ ) after 2, 24 and 48 hours measured by HCA. Data is expressed as a percentage of solvent control; mean \pm standard error of the mean $(\mathrm{SEM}), \mathrm{n}=3 . \mathrm{P} \leq 0.01(* *) \mathrm{P} \leq 0.001\left(^{* * *}\right)$ represent significant pre-lethal cytotoxic effects. 


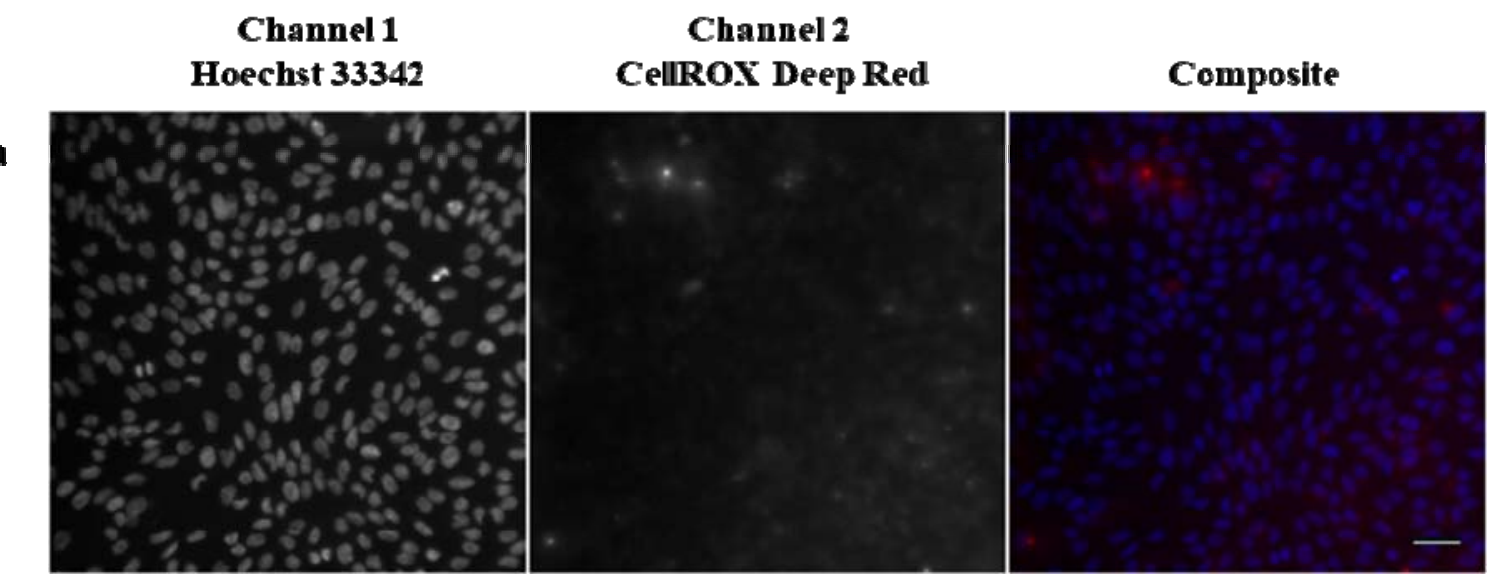

b
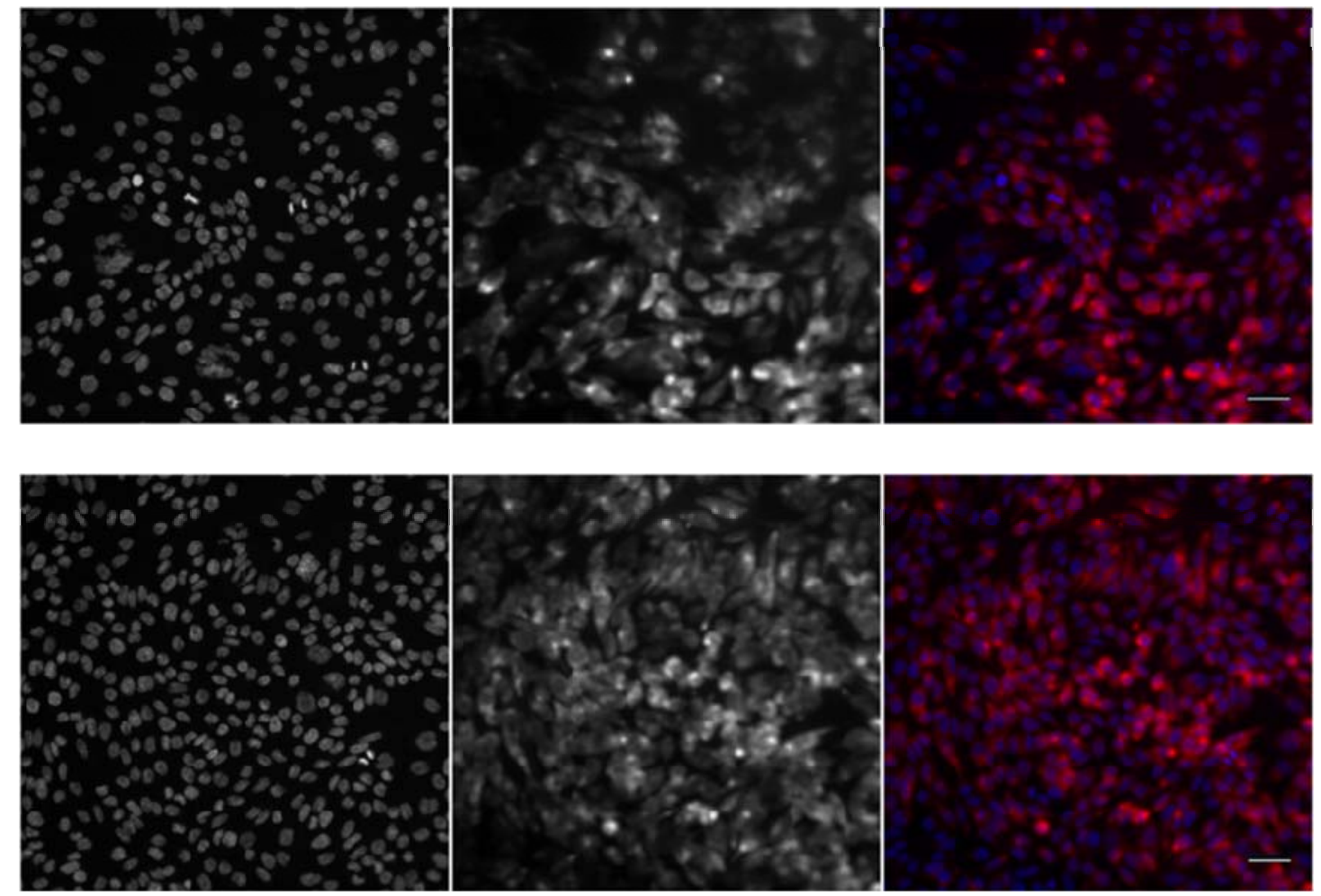

Fig. 10. High content analysis images of changes in ROS intensity of CHO-K1 cells after $48 \mathrm{~h}$ exposure (a) solvent control (DMSO 0.2\%), (b) cytotoxic control (menadione $10 \mu \mathrm{M}$ ) and (c) bDtBPP $0.25 \mu \mathrm{g} / \mathrm{ml}$. Typical HCA micrographs are shown with nuclei (stained by Hoechst 33342, shown in blue) and ROS (stained by CellROX Deep Red, shown in red) x20 objective magnification, scale bars $=200 \mu \mathrm{m}$. Dyes are stated in the image, with composite images containing channels 1 and 2 . 


\section{Discussion}

406

In this study, HCA was used to measure subtle pre-lethal changes in cellular health of 407 CHO-K1 cells following exposure to the leachate bDtBPP after 2, 24 and $48 \mathrm{~h}$. Multiple

408

409

410

411

412

413

414

415

416

417

418

419

420

421

422

423

424

425

426

427 nuclear and mitochondrial pre-lethal cytotoxicity parameters were assessed. Parallel to the HCA, gross cellular cytotoxicity and metabolic activity were also measured using the MTT assay. Viable cells in the MTT assay convert the soluble yellow MTT to insoluble purple formazan by the action of mitochondrial succinate dehydrogenase. Results from the HCA parameter $\mathrm{CN}$ and the MTT assay (Fig. 4) show no significant decrease in CN or cell viability at any concentration of bDtBPP following 2, 24 and $48 \mathrm{~h}$ exposure. However, numerous studies have found bDtBPP to be a leachate which negatively affects $\mathrm{CHO}$ cell growth. The study Hammond et al., (2014) investigated the effects of the leachate obtained on $\mathrm{CHO}$ cell growth and viability after 3 to 4 days incubation at $37^{\circ} \mathrm{C}$ and $48 \mathrm{~h}$ at $50^{\circ} \mathrm{C}$. Multiple varieties of biopharmaceutical manufacturing single-use bags were found to leach bDtBPP and cause suboptimal cell growth and reduced cell viability due to leaching of bDtBPP at concentrations above $0.04 \mathrm{mg} / \mathrm{L}$ (Hammond et al., 2014). A reduction in cell viability was induced in both CHO-K1 and the antibody producing CHO-DP12 cells after exposure to bDtBPP at the highest concentration of $0.25 \mathrm{mg} / \mathrm{L}$ (Kelly et al., 2016). The productivity in the CHO-DP12 cells was reduced by $\sim 50 \%$ under $\mathrm{IC}_{50}$ conditions $(0.1 \mathrm{mg} / \mathrm{L})$ reflecting the reduced cell density. After incubating $\mathrm{CHO}$ cells for 4 days at $0.25 \mathrm{mg} / \mathrm{L}$ bDtBPP, the CHO-K1 and CHO-DP12 cells observed a $40 \%$ and $30 \%$ reduction, respectively, in viable non-apoptotic cells in early and late apoptotic stages (Kelly et al., 2016). Overall the study by Kelly et al., (2016) indicated bDtBPP $(0.035-0.1 \mathrm{mg} / \mathrm{L})$ appeared to slow down cell growth and productivity. Under normal incubation conditions bDtBPP was found to leach out of SUS bags and into cell culture media at process relevant concentrations, 
$4290.025-0.110 \mathrm{mg} / \mathrm{L}$ (Hammond et al., 2014). Therefore, the concentration range of bDtBPP $430(0.005-0.25 \mu \mathrm{g} / \mathrm{ml})$ tested in this study was based upon process relevant leaching concentrations of bDtBPP which induced changes in cell growth performance. Changes in NA and NI can be used as characteristic changes involved in apoptosis or necrosis after exposure to toxic chemicals. In Fig. 5, a significant increase in NI at all tested concentrations of bDtBPP after $48 \mathrm{~h}$ exposure was observed when compared to the solvent control. The increase in NI can also be observed in the HCA image of the Hoechst 33342 stained nuclei in Fig. 6. The intensity of the nuclei normally correlates to the nuclear size or area as a reduction in nuclear area or size results in an increase in NI (Lucke and Mumtsidu, 2009) however, in this study no significant reduction in NA was observed following 2, 24 or $48 \mathrm{~h}$ exposure to bDtBPP at any of the test concentrations. However, not significantly, there was a slight reduction in NA after exposure to bDtBPP after 24 and $48 \mathrm{~h}$ when compared to the solvent control (data not shown). The increase in NI could be due to the onset of apoptosis which results in chromatin condensation. Chromatin condensation is characterised by an increase in DNA staining in the nuclei without a decrease in nuclei size (Cummings and Schnellmann, 2004). The increase in NI without a decrease in CN and NA indicates that bDtBPP can induce changes in nuclear morphology.

As the MTT assay determines mitochondrial activity, it is important to include the HCA mitochondrial parameters as a comparison. The leachate bDtBPP induced a significant dose and time-dependent decrease in $\mathrm{MM}(P \leq 0.05, P \leq 0.01$ and $P \leq 0.001)$ (Fig. 7). After 2 $\mathrm{h}$ exposure, no significant changes in MM were observed however, after $24 \mathrm{~h}$ exposure, a significant decrease in $\mathrm{MM}$ was observed for $0.035,0.05,0.1$ and $0.25 \mu \mathrm{g} / \mathrm{ml} \mathrm{bDtBPP}$, to 90.56, 89.38, 88.47 and 87.27\%, respectively $(P \leq 0.05$ and $P \leq 0.01)$. After $48 \mathrm{~h}$, all concentrations of bDtBPP $(0.005-0.25 \mu \mathrm{g} / \mathrm{ml})$ were found to significantly decrease $\mathrm{MM}$, to 89.49, 86.31, 85.42, 81.67, 79.72 and 76.18\% $(P \leq 0.01$ and $P \leq 0.001)$ (Fig. 7). After 24 and 
$48 \mathrm{~h}$ the cytotoxic control menadione $50 \mu \mathrm{M}$ was too toxic to the $\mathrm{CHO}-\mathrm{K} 1$ cells, reducing the

455

456

457

458

459

460

461

462

463

464

465

466

467

468

469

470

471

472

473

474 cell number to 0 therefore the MM result showed a decrease of $100 \%$ (Fig. 7). Changes in MM can be observed in the HCA images of CHO-K1 cells in Fig. 8, as a decrease in area of green staining of the intracellular content of the mitochondria can be seen when comparing the solvent control (DMSO 0.2\%) image to $0.25 \mu \mathrm{g} / \mathrm{ml}$ bDtBPP (Fig. 8). However, no significant changes in MMP were observed at any of the tested bDtBPP concentrations following exposure for 2, 24 and $48 \mathrm{~h}$. The changes in mitochondrial morphology provide information regarding the mitochondrial health of the cells. The decrease in MM after 24 and $48 \mathrm{~h}$ exposure to bDtBPP could suggest that early stages of apoptosis could be occurring due to shrinking of the cytoplasm without losing the mitochondrial membrane integrity. Mitochondrial morphology is controlled by the regulated mitochondrial dynamic rates of fusion and fission. Mitochondrial fusion and fission in addition to mitophagy are key determinants of mitochondrial quality control (Arnoult et al., 2005; Twig and Shirihai, 2011). The study Arnoult et al., (2005) found that overexpression of pro-fission proteins in the mitochondria caused a decrease in mitochondrial mass by $70 \%$ in $\mathrm{HeLa}$ cells and thus stimulation of fission facilitates mitochondrial mitophagy under certain circumstances. The study Benischke et al., (2017) found that induction of mitophagy resulted in reduction of mitochondrial mass. Mitophagy and fission events play a role in the degradation and segregation of dysfunctional mitochondria. Mitophagy is of importance as dysfunctional mitochondria that are not degraded can produce higher amounts of ROS, be more susceptible to the release of cytochrome $c$ and apoptosis-inducing factor, and thereby, amplify ROS damage (Twig and Shirihai, 2011).

There was no observed significant change in MMP this result would indicate that there was no loss of the mitochondrial membrane integrity by the formation of large conductance pore openings in the mitochondrial membrane, therefore calcium homeostasis 
479 would be maintained, no ATP depletion or rapid progression to cell death occurring (Hunter

480

481

482

483

484

485

486

487

488

489

490

491

492

493

494

495

496

497

498

499

500

501

502

503 and Hapworth, 1979; Osellame et al., 2012). The results from the MTT cell viability and the HCA CN nuclear marker in addition to the MMP marker indicates the stability of the mitochondrial membrane activity within the CHO-K1 cells after exposure to bDtBPP after 48 h. Therefore, it is possible that bDtBPP induced early apoptosis without the loss of mitochondrial membrane potential. The potential of bDtBPP to depolarize the MMP was investigated by Kelly et al., (2016) however mitochondrial membrane depolarization at $0.25 \mathrm{mg} / \mathrm{L}$ was found to be a symptom of cell death and not a cause thus suggesting bDtBPP does not act exclusively at the mitochondria. The study Hammond et al., (2013), observed cellular responses to bDtBPP with a significant decrease in mitochondrial membrane potential.

Optimal functioning of the nucleus and the mitochondria in the female reproductive system and the ovary is vital for maintenance of ovarian reserve and preservation of oocyte quality. Dysfunction in the mitochondria and mitochondrial biogenesis could result in inefficient cellular energy production which could negatively affect oocyte viability and consequently embryonic development (Kasapoğlu and Seli, 2020). Mitochondrial dysfunction could also negatively affect ovarian function and reproduction leading to infertility, spontaneous abortions and birth defects (Kasapoğlu and Seli, 2020).

In the HCA assay, when compared to the solvent control (DMSO 0.2\%) exposure, a significant increase in ROS intensity was observed after $2 \mathrm{~h}$ exposure to $0.25 \mu \mathrm{g} / \mathrm{ml} \mathrm{bDtBPP}$, $24 \mathrm{~h}$ to $0.05,0.1$ and $0.25 \mu \mathrm{g} / \mathrm{ml} \mathrm{bDtBPP}$ and $48 \mathrm{~h}$ exposure to $0.05,0.1$ and $0.25 \mu \mathrm{g} / \mathrm{ml}$ bDtBPP (Fig. 9). A significant dose and time-dependent increase in ROS intensity after exposure to bDtBPP was observed after 2,24 and $48 \mathrm{~h}(P \leq 0.01$ and $P \leq 0.001)$. The time and dose-dependent increase in pre-lethal cytotoxic effects of bDtBPP in this study correlates to previous studies Hammond et al., (2013) and Hammond et al., (2014) which observed a 
time and temperature-dependent increase in bDtBPP leaching and a dose and time-dependent increase in cytotoxicity and cell death. The significant increase in ROS intensity after $48 \mathrm{~h}$ exposure to bDtBPP $(0.25 \mu \mathrm{g} / \mathrm{ml})$ can be seen in Fig. 10 as the red fluorescence increased from the CellROX Deep Red when compared to the solvent control and the cytotoxic control (menadione $10 \mu \mathrm{M}$ ). ROS production is a natural process which occurs during the generation of energy in the mitochondria (Kasapoğlu and Seli, 2020). The generation of ROS including oxygen radicals and hydrogen peroxide are also produced during the mitochondrial oxidation of nutrients with the majority of endogenous ROS through the leakage of electrons along the electron transport chain (Kasapoğlu and Seli, 2020; Quinlan et al., 2013; Rigoulet et al., 2011). In addition, ROS generation occurs in the early events of apoptosis (Camilleri-Broët et al., 1998). The mitochondrial free radical theory of aging proposed, the detrimental effects of excessive intracellular ROS on the cell leading to oxidative damage as the determinant of cellular life span. The mitochondrial free radical theory of aging also proposed that ROS are toxic as they result in mitochondrial DNA (mtDNA) mutations that cause a bioenergetic deficit, which, in turn drives aging (Harman, 1956). A deficit in bioenergetic could result in initial damage to mtDNA leading to further mtDNA damage by increasing ROS generation, therefore leading to apoptosis (Richter, 1995). Excessive levels of ROS may be associated with mitochondrial and cellular dysfunction which is implicated in metabolic and age related disorders and neurodegenerative diseases (Osellame et al., 2012; Kasapoğlu and Seli, 2020).

One of the major pathways bDtBPP may induce oxidative stress in the CHO-K1 cells is via the activation of inducible nitric oxide synthase (iNOS). The enzyme iNOS is not present under normal conditions in most cells therefore its expression is inducible and is associated with inflammation and malignant diseases such as ovarian cancer. The activation of iNOS expression, enzyme activation and subsequent free radical gas nitric oxide (NO) production is a complex process that undergoes multilevel control and is regulated by 
transcriptional from mRNA induction to post-transcriptional mechanisms including the modulation of full enzymatic activity (Kielbik, Szulc-Kielbik and Klink, 2019). Activation of the inflammatory oxidative enzyme iNOS has been linked to the generation of highly reactive ROS and NO which in turn affects various cellular components and implications in the processes of ovulation and atresia-related apoptosis (Zackrisson et al., 1996; Koppula et al., 2012). Response to cellular stress such as the production of NO can induce apoptosis through the activation of the p53 pathway and downregulating the anti-apoptotic proteins (Burke et al., 2013; Burns and El-Deiry, 1999; Singh and Gupta, 2011). Oxidative stress was also observed in the study Kelly et al., (2016) with up regulation of the gene heme oxygenase 1 (HMOX1) thus suggesting bDtBPP elicits a physiological stress and potentially elicit oxidative damage to host cell proteins in the $\mathrm{CHO}$ cells. Inhibited or reduced cell growth along with oxidative cellular stress could suggest activation of the p53 pathway therefore leading to apoptosis.

The high production of ROS in this study was interesting as the test compound bDtBPP is a breakdown product of the antioxidant stabiliser TBPP; antioxidants are known for their role in cellular response to prevent oxidative stress by scavenging free radicals, catalysing the oxidation of molecules and sequestering transition metal ions and preventing Fenton reactions (Chapple, 1997). The increased ROS production observed by the CellROX Deep Red dye in CHO-K1 cells after exposure to bDtBPP may be due to ROS production in the mitochondrial electron-transport chain which is not as well regulated by enzymes and therefore increase oxidative stress as antioxidant defences are inadequate to inactivate ROS production.

The study Kelly et al., (2019) identified that conditioned media generated from an older single-use bioreactor film (F-1) over time inhibits $\mathrm{CHO}$ cell growth and antibody productivity when compared to a more modern film (F-2) with lower levels of Irgafos 168. 
554 Reduced growth of CHO cells in F-1 conditioned media exhibited a weakened capacity for 555 ATP synthesis through diminished electron transport through the mitochondrial electron transport system and an increased response to oxidative stress (Kelly et al., 2019). Gene

557

558

559

560

561

562

563

564

565

566

567

568

569

570

571

572

573

574

575

576

577

578

ontology analysis of the differentially expressed proteins in $\mathrm{CHO}$ cells cultured in F-1 conditioned media revealed the enrichment for biological processes associated with oxidative stress and mitochondrial respiratory chain complexes. Mitochondrial activity was weakened due to the downregulation of a subset of proteins involved in NADH dehydrogenase activity (Kelly et al., 2019). These potentially metabolically compromised cells exhibited a reduction in oxidative phosphorylation activity in addition to lower glycolytic metabolism, which are characteristic of poor growing cells (Kelly et al., 2019). The study Kelly et al., (2019) observed cytotoxic effects of the films after 3 (F-2) and 7 (F-1) days, whilst pre-lethal cytotoxic effects of bDtBPP on the CHO-K1 cells in the current study were observed after 24 and $48 \mathrm{~h}$. Another study reported that bDtBPP accumulates to levels ranging from $0.025-0.11$ mg/L over 3-4 days incubation under bioprocess-relevant conditions (Hammond et al., 2014). Therefore, it would be reasonable to suggest reducing the biopharmaceutical production period in order to prevent toxic accumulation of the leachate bDtBPP into cell culture media.

Multiple varieties of biopharmaceutical manufacturing single-use bags were found to leach bDtBPP (Hammond et al., 2014). Leachates from plastic materials such as bisphenol-A and phthalates can negatively impact human health (Moreira et al., 2015; Muncke et al., 2017; Yang et al., 2011). The leachate bDtBPP could potentially pose a threat to the patient if bDtBPP is present in the active biopharmaceutical ingredient after persisting through purification processes, the potential toxicity to the bioprocess itself, from the final container closure system or packaging components such as prefilled syringes and/or processing equipment (Kelly et al., 2019; Markovic, 2007). The study Kelly et al., (2019) reported that bDtBPP $(0.1-0.25 \mu \mathrm{g} / \mathrm{ml})$ possessed the potential to act as an endocrine disruptor, 
antagonising the androgen receptor transcriptional activity in the androgen responsive TARM-Luc cell line. Androgen receptor antagonism could disrupt normal androgen signalling in humans and could lead to implications in the reproductive health of males and females potentially disrupting sexual differentiation and/or fertility (Chang et al., 2013; Luccio-Camelo and Prins, 2011). However, after the purification processes the leachate bDtBPP may potentially be removed in the later stages of the bioprocessing pipeline and therefore may not pose a threat to the patient (Owczarek et al., 2019).

Overall, exposure to bDtBPP has been found to lead to ROS accumulation and cellular oxidative stress. The mitochondrial mass can shrink and nuclear intensity increase without inducing a reduction in cell number. The level of ROS produced by the CHO-K1 cells after exposure to bDtBPP may have been sufficient to cause mtDNA mutation or damage and mitochondrial shrinkage but not enough to induce cell death. This further illustrates the ability of the HCA assay to identify early signs and/or reversible signs of cellular stress and pre-lethal cytotoxicity.

\section{Conclusion}

This study confirms that the leachate bDtBPP, at process relevant concentrations, can induce subtle pre-lethal cytotoxic effects on CHO-K1 cellular health. The leachate bDtBPP induced an increase in NI after $48 \mathrm{~h}$ exposure. A dose- and time- dependent reduction in MM, in addition a dose- and time- dependent increase in ROS intensity was observed. Exposure to bDtBPP induced the intensity of ROS and likely induced the onset of cell apoptosis due to the increase in NI and reduction in MM. These toxicological findings identify that bDtBPP can induce oxidative stress and impact nuclear and mitochondrial health and morphology without inducing a reduction in cell viability. Subtle pre-lethal changes in cellular health and 

morphology following exposure to bDtBPP may cause CHO-K1 cells to become unhealthy 604 without reducing the cell number or viability. This study reinforces the benefits for the 605 biopharmaceutical industry and improved CHO-K1 cellular health by switching to alternative 606 SUS plastics which do not leach bDtBPP.

\section{Acknowledgements}

608 The authors wish to express gratitude to Professor Martin Clynes from Dublin City 609 University for proof reading the article.

610 This work was supported by the PhD Studentship funding provided by the Department for the 611 Economy (DfE) Northern Ireland. 


\section{References}

615

616

617

618

619

620

621

622

623

624

625

626

627

628

629

630

631

632

633

634

635

636

637

638

639

640

641

642

643

644

645

646

647

648

649

650

651

652

Abdalah, R. Wei, L. Francis, K. et al Yu, S.P. (2006). Valinomycin-induced apoptosis in Chinese hamster ovary cells. Neuroscience Letters. 405 (1-2), p68-73. https://doi.org/10.1016/j.neulet.2006.06.055.

Abraham, V.C. Taylor, L. and Haskins, J.R. (2004). High content screening applied to large-

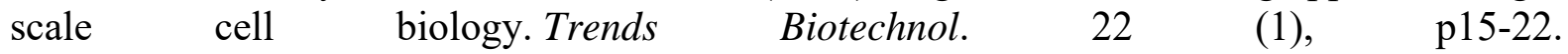
https://doi.org/10.1016/j.tibtech.2003.10.012.

Akopova, O.V. Kolchinskaya, L. I. Nosar, V.I. Bouryi, V.A. Man'kovskaya, I.N. et al Sagach, V.F. (2013). Effect of Valinomycin-Induced Potassium Influx on the Formation of Reactive Oxygen Species in the Rat Brain Mitochondria. Neurophysiology. 45 (5/6), p388395. https://doi.org/10.1007/s11062-013-9384-3.

Arends, M. J. and Wyllie, A.H. (1991). Apoptosis: Mechanisms and Roles in Pathology. International Review of Experimental Pathology. 32, p223-254. https://doi.org/10.1016/B978-0-12-364932-4.50010-1.

Arnoult, D. Rismanchi, N. Grodet, A. Roberts, R.G. Seeburg, D.P. Estaquier, J. Sheng, M. et al Blackstone, C. (2005). Bax/Bak-dependent Release of DDP/TIMM8a Promotes Drp1mediated Mitochondrial Fission and Mitoptosis During Programmed Cell Death. Curr Biol. 15 (23), p 2112-2118. https://doi.org/10.1016/j.cub.2005.10.041.

Benischke, A. Vasanth, S. Miyai, T. Katikireddy, K.R. White, T. Chen, Y. Halilovic, A. Price, M. Price. F. Liton, P.B. et al Jurkunas, U.V. (2017). Activation of mitophagy leads to decline in Mfn2 and loss of mitochondrial mass in Fuchs endothelial corneal dystrophy. Scientific Reports 7 (1), p6656. https://doi.org/10.1038/s41598-017-06523-2.

Buckman, J.F. Hernández, H. Kress, G.J. Votyakova, T.V. Pal, S. et al Reynolds, I.J. (2001). MitoTracker labeling in primary neuronal and astrocytic cultures: influence of mitochondrial membrane potential and oxidants. Journal of Neuroscience Methods. 104 (2), p165-176. https://doi.org/10.1016/S0165-0270(00)00340-X.

Burke, A.J. Sullivan, F.J. Giles, F.J. et al Glynn, S.A. (2013). The yin and yang of nitric oxide in cancer progression. Carcinogenesis. 34 (3), p503-512. https://doi.org/10.1093/carcin/bgt034.

Burns, T.F. and El-Deiry, W.S. (1999). The p53 Pathway and Apoptosis. J Cell Physiol. 181 (2), p231-239. $\quad$ https://doi.org/10.1002/(SICI)1097-4652(199911)181:2<231::AIDJCP5>3.0.CO;2-L.

Butler, M. and Meneses-Acosta, A. (2012). Recent advances in technology supporting biopharmaceutical production from mammalian cells. Appl Microbiol Biotechnol . 96 (4), p885-894. https://doi.org/10.1007/s00253-012-4451-z.

Camilleri-Broët, S. Vanderwerff, H. Caldwell, E. et al Hockenbery, D. (1998). Distinct Alterations in Mitochondrial Mass and Function Characterize Different Models of Apoptosis. Experimental Cell Research. $239 \quad$ (2), $\quad$ p277 $\quad$ - 292. https://doi.org/10.1006/excr.1997.3899. 

Physiological Roles in Male and Female Reproductive Systems: Lessons Learned from ARKnockout Mice Lacking AR in Selective Cells. Biology of Reproduction. 89 (1), p1-16. https://doi.org/10.1095/biolreprod.113.109132.

657 Chapple, I. L. C. (1997). Reactive oxygen species and antioxidants in inflammatory 658 diseases. Journal of Clinical Periodontology. $24 \quad$ (5), p287-296. 659 https://doi.org/10.1111/j.1600-051x.1997.tb00760.x.

660 Chazotte, B. (2011). Labeling Nuclear DNA with Hoechst 33342. Cold Spring Harb Protoc. 661 2011 (1), p83-86. https://doi.org/10.1101/pdb.prot5557.

663

Clarke, R. Connolly, L. Frizzell, C and Elliott, C.T. (2015). High content analysis: a sensitive tool to detect and quantify the cytotoxic, synergistic and antagonistic effects of chemical contaminants in foods. Toxicology Letters. $233 \quad$ (3), p278-286. 665 https://doi.org/10.1016/i.toxlet.2015.01.011.

666 Cottet-Rousselle, C. Ronot, X. Leverve, X. et al Mayol, J-F. (2011). Cytometric Assessment 667 of Mitochondria Using Fluorescent Probes. Cytometry Part A. 79A (6), p405-425. 668 https://doi.org/10.1002/cyto.a.21061.

669 Cummings, B.S. and Schnellmann, R.G. (2004). Measurement of Cell Death in Mammalian 670 Cells. Curr Protoc Pharmacol.. $25 \quad$ (1), p12.8.1-12.8.22. 671 https://doi.org/10.1002/0471141755.ph1208s25.

672 Duchen, M.R. (2000). Mitochondria and calcium: from cell signalling to cell death. Journal 673 of Physiology. 529 (1), p57-68. https://doi.org/10.1111/j.1469-7793.2000.00057.x.

674 Giuliano, K.A. Haskins, J.R. and Taylor, D.L. (2004). Advances in high content screening for 675 drug discovery. ASSAY and Drug Development Technologies. 1 (4), p565-577. 676 https://doi.org/10.1089/154065803322302826.

677 Hammond, M. Marghitoiu, L. Lee, H. Perez, L. Rogers, G. et al Nashed-Samuel, Y. (2014). 678 A Cytotoxic Leachable Compound from Single-Use Bioprocess Equipment that Causes Poor 679 Cell Growth Performance. Biotechnol Progress. $30 \quad$ (2), p332-337. 680 https://doi.org/10.1002/btpr.1869.

681 Hammond, M. Nunn, H. Rogers, G. Lee, H. Marghitoiu, A.L. Perez, L. Nashed-Samuel, Y. 682 Anderson, C. Vandiver, M. et al Kline, S. (2013). Identification of a leachable compound 683 detrimental to cell growth in single-use bioprocess containers. PDA J Pharm Sci Technol. 67 684 (2), p123-134. https://doi.org/10.5731/pdajpst.2013.00905.

685 Harman, D. (1956). Aging: a theory based on free radical and radiation chemistry. Journal of 686 Gerontology. 11 (3), p298-300. https://doi.org/10.1093/geronj/11.3.298.

687 Hunter, D.R and Haworth, R.A. (1979). The Ca2+-induced membrane transition in 688 mitochondria: I. The protective mechanisms. Archives of Biochemistry and Biophysics. 195 689 (2), P453-459. https://doi.org/10.1016/0003-9861(79)90371-0.

690 Kasapoğlu, I and Seli, E. (2020). Mitochondrial dysfunction and ovarian 691 aging. Endocrinology. 161 (2), p1-11. https://doi.org/10.1210/endocr/bqaa001.

692 Kashatus, D.F. (2018). The regulation of tumor cell physiology by mitochondrial 693 dynamics. Biochemical and Biophysical Research Communications. 500 (1), p9-16. 694 https://doi.org/10.1016/j.bbrc.2017.06.192. 
Kelly, P.S. Dorival-García, N. Paré,S. Carillo, S. Ta, C. Alarcon Miguez, A. Coleman, O. Harper, E. Shannon, M. Henry, M. Connolly, L. Clynes, M. Meleady, P. Bones, J. et al Barron, N. (2019). Improvements in Single-Use Bioreactor Film Material Composition Leads to Robust and Reliable Chinese Hamster Ovary Cell Performance. Biotechnology Progress. 35 (4), e2824. https://doi.org/10.1002/btpr.2824.

Kelly, P.S. McSweeney, S. Coleman, O. Carillo, S. Henry, M. Chandran, D. Kellett, A. Bones, J. Clynes, M. Meleady, P. et al Barron, N. (2016). Process-relevant concentrations of the leachable bDtBPP impact negatively on $\mathrm{CHO}$ cell production characteristics. Biotechnology Process. 32 (6), p1547-1558. https://doi.org/10.1002/btpr.2345.

Kielbik, M. Szulc-Kielbik, I. and Klink, M. (2019). The Potential Role of iNOS in Ovarian Cancer Progression and Chemoresistance. Int $\quad J \quad M o l$ Sci. 20 (7), p1751. https://doi.org/10.3390/ijms20071751.

Koppula, S. Kumar, H. Kim, I. S. et al Choi, D-K. (2012). Reactive Oxygen Species and Inhibitors of Inflammatory Enzymes, NADPH Oxidase, and iNOS in Experimental Models of Parkinson's Disease. Mediators Inflamm. $2012 \quad$ (823902), $\quad$ p1-16. https://doi.org/10.1155/2012/823902.

Kurutas, E. B. (2016). The importance of antioxidants which play the role in cellular response against oxidative/nitrosative stress: current state. Nutrition Journal. 15 (1), p71. https://doi.org/10.1186/s12937-016-0186-5.

Li, X. Chen, M. Yang, Z. Wang, W. Lin, H. et al Xu, S. (2018). Selenoprotein S silencing triggers mouse hepatoma cells apoptosis and necrosis involving in intracellular calcium imbalance and ROS-mPTP-ATP. Biochimica et Biophysica Acta (BBA) - General Subjects. 1862 (10), p2113-2123. https://doi.org/10.1016/j.bbagen.2018.07.005.

Liu, J. Kennedy, J.H. Ronk, M. Marghitoiu, L. Lee, H. et al Nashed-Samuel, Y. (2014). Ambient Analysis of Leachable Compounds From Single-Use Bioreactors With Desorption Electrospray Ionization Time-Of-Flight Mass Spectrometry. Rapid Commun Mass Spectrom. 28 (21), p2285-2291. https://doi.org/10.1002/rcm.7021.

Luccio-Camelo, D.C. and Prins, G.S. (2011). Disruption of Androgen Receptor Signaling in Males by Environmental Chemicals. J Steroid Biochem Mol Biol. 127 (1-2), p74-82. https://doi.org/10.1016/j.jsbmb.2011.04.004.

Lucke, J and Mumtsidu, E. (2009). A Multiparametric Live-Cell Cytotoxicity Analysis using the Operetta. Available: https://www.perkinelmer.com/labsolutions/resources/docs/APP_MultiparametricLiveCellCytotoxicityOperetta.pdf. Last accessed 25th March 2020.

Markovic, I. (2007). Evaluation of Safety and Quality Impact of Extractable and Leachable Substances in Therapeutic Biologic Protein Products: A Risk-Based Perspective. Expert Opin Drug Saf. 6 (5), p487-491. https://doi.org/10.1517/14740338.6.5.487.

Moreira, M. A. André, L.C. and Cardeal, Z. L. (2015). Analysis of plasticiser migration to meat roasted in plastic bags by SPME-GC/MS. Food Chemistry. 178 (1), p195-200. https://doi.org/10.1016/j.foodchem.2015.01.078. 
Muncke, J. Backhaus, T. Geueke, B. Maffini, M.V. Martin, O.V. Myers, J. P. Soto, A.M. Trasande, L. Trier, X. et al Scheringer, M. (2017). Scientific Challenges in the Risk Assessment of Food Contact Materials. Environ Health Perspect. 125 (9), 095001. https://doi.org/10.1289/EHP644.

O'Brien, P. and Haskins, J.R. (2007) In Vitro Cytotoxicity Assessment. In: Taylor, D.L. Haskins, J.R. Giuliano, K.A. (Eds) High Content Screening. Methods in Molecular Biology, vol 356. NJ, USA: Humana Press. p415-425. https://doi.org/10.1385/1-59745$\underline{217-3: 415}$

Osellame, L.D. Blacker, T.S. and Duchen, M.R. (2012). Cellular and molecular mechanisms of mitochondrial function. Best Practice \& Research Clinical Endocrinology \& Metabolism. 26 (6), p711-723. https://doi.org/10.1016/i.beem.2012.05.003.

Owczarek, B. Gerszberg, A. and Hnatuszko-Konka, K. (2019). A Brief Reminder of Systems of Production and Chromatography-Based Recovery of Recombinant Protein Biopharmaceuticals. BioMed Research International. 2019 (Article ID 4216060), p1-13. https://doi.org/10.1155/2019/4216060.

Parone, P.A. Da Cruz, S. Tondera, D. Mattenberger, Y. James,D.I. Maechler, P. Barja, F. et al Martinou, J-C. (2008). Preventing Mitochondrial Fission Impairs Mitochondrial Function and Leads to Loss of Mitochondrial DNA. PLoS One. 3 (9), e3257. https://doi.org/10.1371/journal.pone.0003257.

Purschke, M. Rubio, N. Held, K.D. et al Redmond, R.W. (2010). Phototoxicity of Hoechst 33342 in Time-Lapse Fluorescence Microscopy. Photochem Photobiol Sci. 9 (12), p16341639. https://doi.org/10.1039/c0pp00234h.

Quinlan, C.L. Perevoshchikova, I.V. Hey-Mogensen, M. Orr, A.L. et al Brand, M.D. (2013). Sites of reactive oxygen species generation by mitochondria oxidizing different substrates. Redox Biol. 1 (1), p304-312. https://doi.org/10.1016/j.redox.2013.04.005.

Richter, C. (1995). Oxidative damage to mitochondrial DNA and its relationship to ageing. The International Journal of Biochemistry \& Cell Biology. 27 (7), p647-653. https://doi.org/10.1016/1357-2725(95)00025-K.

Rigoulet, M. Yoboue, E. D. et al Devin, A. (2011). Mitochondrial ROS generation and its regulation: mechanisms involved in $\mathrm{H} 2 \mathrm{O} 2$ signaling. Antioxidants and Redox signalling. 14 (3), p459-468. https://doi.org/10.1089/ars.2010.3363.

Rinaldi, F. Motti, D. Ferraiuolo, L. and Kaspar, B.K. (2017). High Content Analysis in Amyotrophic Lateral Sclerosis. Mol Cell Neurosci. 80, p180-191. https://doi.org/10.1016/j.mcn.2016.12.001

Silva, J.P. Köhler, M. Graff, C. Oldfors, A. Magnuson, M. A. Berggren, P.O. et al Larsson, N.G. (2000). Impaired insulin secretion and beta-cell loss in tissue-specific knockout mice with mitochondrial diabetes. Nature Genetics. $26 \quad$ (3), p336-340. https://doi.org/10.1038/81649. 
Singh, S. and Gupta, A. K. (2011). Nitric oxide: role in tumour biology and iNOS/NO-based anticancer therapies. Cancer Chemotherapy and Pharmacology volume. 67 (6), p1211-1224. https://doi.org/10.1007/s00280-011-1654-4.

Susin, S.A. Lorenzo, H.K. Zamzami, N. Marzo, I. Snow, B.E. Brothers, G.M. Mangion, J. Jacotot, E. Costantini, P. Loeffler, M. Larochette, N. Goodlett, D.R. Aebersold, R. Siderovski, D.P. Penninger J. M. et al Kroemer, G. (1999). Molecular characterization of mitochondrial apoptosis-inducing factor. Nature. 397 (6718), p441-446.

780 https://doi.org/10.1038/17135.

781 Twig, G. and Shirihai, O.S. (2011). The Interplay Between Mitochondrial Dynamics and 782 Mitophagy. Antioxid Redox Signalling. $14 \quad$ (10), p1939-1951.

783 https://doi.org/10.1089/ars.2010.3779.

784 Wilson, J. Berntsen, H. Zimmer, K. Frizzell, C. Verhaegen, S. Ropstad, E. and Connolly, L. 785 (2016). Effects of defined mixtures of persistent organic pollutants (POPs) on multiple cellular responses in the human hepatocarcinoma cell line, HepG2, using high content analysis screening. Toxicology and Applied https://doi.org/10.1016/j.taap.2016.01.001.

789 Yang, C.Z. Yaniger, S.I. Jordan, V.C. Klein, D.J. et al Bittner, G.D. (2011). Most plastic 790 products release estrogenic chemicals: a potential health problem that can be solved. Environ 791 Health Perspect. 119 (7), p989-996. https://doi.org/10.1289/ehp.1003220.

792 Zackrisson, U. Mikuni, M. Wallin, A. Delbro, D. Hedin, L. et al Brännström, M. (1996). 793 Cell-specific localization of nitric oxide synthases (NOS) in the rat ovary during follicular 794 development, ovulation and luteal formation. Hum Reprod. 11 (12), p2667-2673. 795 https://doi.org/10.1093/oxfordjournals.humrep.a019189. 